\title{
EFFECT OF FOLIAR SPRAYING WITH SEAWEEDS EXTRACT, CHITOSAN AND POTASSIUM SILICATE ON ROSMARINUS OFFICINALIS L. PLANTS IN SANDY SOIL
}

\author{
A.A. Waly ${ }^{*}$; Y.M. Abd El-Fattah*; M.A.E. Hassan*; E.A.E. El-Ghadban ${ }^{* *}$ \\ and Alia S. Abd Alla** \\ *Floriculture, Medicinal \& Aromatic Plants, Hort. Dept., Agric. Fac., Suez Canal Univ., \\ Egypt \\ ${ }^{* *}$ Medicinal \& Aromatic plants Research Dept., Hort. Res. Inst., Agric. Res. Center, Egypt
}

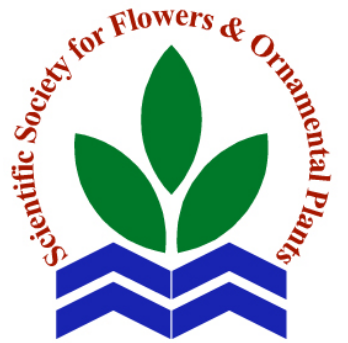

Scientific J. Flowers \& Ornamental Plants, 6(3):191-209 (2019).

Received:

5/12/2019

Accepted:

28/12/2019

ABSTRACT: The present study was carried out at the Experimental Farm, Horticulture Department, Faculty of Agriculture, Suez Canal University during two seasons of 2017/2018 and 2018/2019 to study the effect of foliar application of seaweeds extract at 2, 4 and $6 \mathrm{ml} / \mathrm{l}$, chitosan at 2, 4 and $6 \mathrm{ml} / \mathrm{l}$ and potassium silicate at 6,9 and $12 \mathrm{ml} / \mathrm{l}$ as well as the interaction between seaweeds extract and chitosan on growth, biochemical, and essential oil characteristics of rosemary plants grown in a sandy soil. These compounds were applied as foliar spray three times after 15 days from planting. The results showed that foliar applications of seaweeds extract at $6 \mathrm{ml} / \mathrm{l}$, chitosan at $6 \mathrm{ml} / \mathrm{l}$ and potassium silicate at $12 \mathrm{ml} / \mathrm{l}$ significantly affected all studied parameters compared with control. The results clearly indicated that the different applied treatments increased the measured growth characteristics i.e. plant height, number of branches/plant, fresh and dry weights as well parallel increase of photosynthetic pigments. Also, constituents of $\mathrm{N}, \mathrm{P}, \mathrm{K}$, total carbohydrates, percentage of essential oil and the G.L.C. of essential oil of plant age were existed in the two assigned seasons. In addition, the most effective combined treatment was that of seaweed at $6 \mathrm{ml} / \mathrm{l}+$ chitosan at $6 \mathrm{ml} / \mathrm{l}$ in this respect.

Key words: Rosemary, Rosmarinus officinalis L., seaweed extract, chitosan, potassium silicate, growth and essential oil.

\section{INTRODUCTION}

Rosemary (Rosmarinus officinalis L.) is a member of the mint family, Lamiaceae. It is an evergreen, perennial shrub that is endemic to the Mediterranean Region and has been cultivated since ancient times (Simon et al., 1984). Numerous studies were conducted on medicinal plants to increase their productivity using different methods. Chitosan is a natural biopolymer modified from chitin, which can be transformed into chitosan by extracting the acetyl group and turn it into amino. Many investigators reported that using chitosan as foliar spray increased vegetative growth, yield and quality of different crops including Castro et al. (2016) on coriander; Mahdavi (2013) on isabgol and Kim et al. (2005) on basil. Furthermore, chitosan has been recognized as a product to enhance crop production due to its bioactivities: biodegradability. growth stimulation and seed germination, increasing nutrient uptake, reducing oxidative stress, increasing chlorophyll content, photosynthetic and chloroplast enlargement in the leaves, antifungal, antiviral and antibacterial properties (Hadrami et al., 2010 and Hadwiger, 2013).

Seaweeds extract plays role as an activator of cell division, and gives rise to antioxidants levels for protection against 


\section{A.A. Waly et al.}

adverse environmental conditions (Smirnoff, 1995). Nasiroleslami and Safaridolatabad (2014) reported that foliar application of seaweed increased vegetative growth of dill plants.

Horticultural crops take potassium in large quantities, especially at tuberlization filling stages. Potassium fertilizer application can be performed in several ways by banding, fertigation or by spraying liquid fertilizers on to the leaves (Magen, 2004). Potassium is an important nutrient for plant meristematic growth and physiological functions, including regulation of water and gas exchange in plants, protein synthesis, enzyme activation, photosynthesis and carbohydrate translocation in plants. Potassium has favourable effects on metabolism of nucleic acids, proteins, vitamins and growth substances, energy transfer, phloem transport, cation-anion balance and enabling their ability to resist pests and diseases (Wang et al., 2013). Potassium silicate is a source of highly soluble silicon; it is used in agricultural production system primarily as a silicon fertilizer (Abou-Baker et al., 2011). Foliar spray with potassium silicate increased plant growth, chlorophyll content, $\mathrm{N}, \mathrm{P}$ and $\mathrm{K}$ contents in the leaves and yield and its components (Wand and Galletta, 1998) on strawberries.

Therefore, this study was aimed to investigate the effect of seaweed extract, chitosan and potassium silicate on the growth, herb, essential oil yield and constituents as well as chemical composition of rosemary (Rosmarinus officinalis L.) plant.

\section{MATERIALS AND METHODS}

The present study was carried out at the Experimental Farm, Horticulture Department, Faculty of Agriculture, Suez Canal University, Egypt during two seasons of 2017/2018 and 2018/2019 to investigate the effect of seaweed extract, chitosan and potassium silicate on the growth, herb, essential oil yield and constituents as well as chemical composition of rosemary (Rosmarinus officinalis L.) plant.

\section{Experimental design:}

Healthy terminal stem-cuttings of 15-20 $\mathrm{cm}$ tall with at least 3-4 leaves of rosemary (R. officinalis L.) plants were treated by dipping in 1000 ppm IAA for $5 \mathrm{~min}$ and planted during two successive seasons of 2017/2018 and 018/2019 at Experimental Farm, Faculty of Agriculture, Suez Canal University. The plants were treated by spraying extracts of seaweeds (2, 4 and 6 $\mathrm{ml} / \mathrm{l}$ water), chitosan (2, 4 and $6 \mathrm{ml} / \mathrm{l}$ water) and potassium silicate $(6,9$ and $12 \mathrm{ml} / \mathrm{l}$ water) as well as combinations between seaweeds and chitosan $(2: 2,2: 4,2: 6,4: 2$, $4: 4,4: 6,6: 2,6: 4$, and $6: 6 \mathrm{ml} / \mathrm{l})$. Chemical and physical properties of the experimental soil are shown in Table (a), while chemical properties of the used water are shown in Table (b). Oligo-X was used as a source of seaweeds extract, chemical constituents of Oligo-X are shown in Table (c).

\section{Morphological attributes:}

Data of the morphological traits were recorded in each cutting (after 3-4 months) separately for estimating the variability in the effect of the different treatments on growth plant. These data included plant height $(\mathrm{cm})$, number of branches/plant, fresh and dry weights of plant and leaves (g/plant). The first cut was done on July and the second cut was done on October of both seasons.

\section{Chemical analysis:}

- The contents of chlorophylls a, b and carotenoids were determined in the fresh leaves as described by Mazumdar and Majumder (2003). While, total chlorophylls were determined (mg/g f.w.) according to Wettestein (1957).

- Contents of leaf minerals were estimated according to Piper (1947).

- Nitrogen percentage was determined according to the micro-Kjeldhle method as described by Jackson (1967). 
Table a. Chemical and physical properties of the experimental soil.

\begin{tabular}{ccccccccc}
\hline $\mathbf{E C}$ & \multicolumn{4}{c}{ Anions (ppm) } & \multicolumn{4}{c}{ Cations (ppm) } \\
$\mathbf{d S ~ m}^{-1}$ & $\mathbf{C O}_{3^{-}}$ & $\mathbf{H C O}_{3^{-}}$ & $\mathbf{C l}$ & $\mathbf{S O}^{-}$ & $\mathbf{C a}^{+-}$ & $\mathbf{M g}^{++}$ & $\mathbf{N a}^{+}$ & $\mathbf{K}^{+}$ \\
0.58 & -- & 2.12 & 2.54 & 1.67 & 4.61 & 0.83 & 0.82 & 0.08 \\
\hline & \multicolumn{3}{c}{ Macro-elements (mg/1000g) } & \multicolumn{4}{c}{ Micro-elements (mg/1000 g) } \\
$\mathbf{p H}$ & $\mathbf{N}$ & $\mathbf{K}$ & $\mathbf{P}$ & & $\mathbf{C u}^{++}$ & $\mathbf{F e}^{++}$ & $\mathbf{M n}^{++}$ & $\mathbf{Z n}^{++}$ \\
8.0 & 53.0 & 55.8 & 0.90 & & 0.90 & 2.20 & 1.54 & 0.59 \\
\hline
\end{tabular}

Table b. Chemical properties of water used.

\begin{tabular}{|c|c|c|c|c|c|c|c|c|}
\hline \multirow{3}{*}{$\begin{array}{c}\text { EC } \\
\text { dS.m-1 } \\
0.40\end{array}$} & \multicolumn{4}{|c|}{ Anions (ppm) } & \multicolumn{4}{|c|}{ Cations (ppm) } \\
\hline & $\mathrm{CO}_{3}{ }^{-}$ & $\mathrm{HCO}_{3}{ }^{-}$ & $\mathrm{Cl}^{-}$ & $\mathrm{SO}_{4}^{-}$ & $\mathrm{Ca}^{++}$ & $\mathbf{M g}^{++}$ & $\mathrm{Na}^{+}$ & $\mathbf{K}^{+}$ \\
\hline & -- & 1.42 & 0.85 & 2.00 & 2.82 & 1.08 & 0.26 & 0.11 \\
\hline \multicolumn{9}{|c|}{ Elements mg/l } \\
\hline pH & $\mathrm{NH}_{4}{ }^{+}$ & $\mathrm{NO}_{3}{ }^{-}$ & B & $\mathbf{C u}$ & Fe & Mn & $\mathbf{P}$ & Zn \\
\hline 7.10 & 1.05 & 1.75 & 0.30 & 0.20 & 0.20 & 0.011 & 1.50 & 0.30 \\
\hline
\end{tabular}

Table c. Chemical constituents of Oligo-X seaweed extract.

\begin{tabular}{|c|c|c|c|c|c|c|c|c|c|c|c|}
\hline \multirow[b]{2}{*}{ نٌ } & \multirow[b]{2}{*}{ 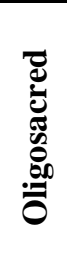 } & \multirow[b]{2}{*}{ 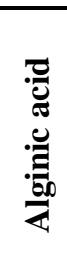 } & \multirow[b]{2}{*}{ 芯 } & \multirow[b]{2}{*}{ 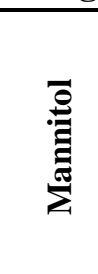 } & \multirow[b]{2}{*}{ Oָ } & \multirow[b]{2}{*}{ 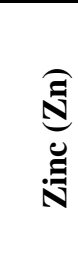 } & \multirow[b]{2}{*}{ 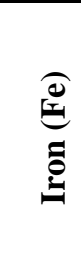 } & \multirow[b]{2}{*}{ 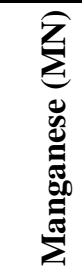 } & \multicolumn{3}{|c|}{ Growth regulators } \\
\hline & & & & & & & & & 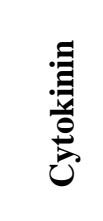 & 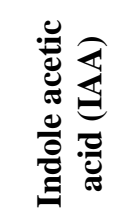 & 竞 \\
\hline$\%$ & 3 & 5 & 0.003 & 0.001 & 4.71 & 0.13 & 0.12 & 0.10 & 0.001 & 0.0002 & 0.02 \\
\hline
\end{tabular}

- Phosphorus percentage was colorimetrically determined according to Murphy and Reilly (1962).

- Potassium percentage was determined using the atomic absorption spectrophotometer (3300) according to Wilde et al. (1985).

- Total carbohydrate was determined according to Herbert et al. (1971).

- Essential oil percentage (EO) was determined according to British Pharmacopoeia (2000). The essential oil constituents of dry herb weight were analyzed using gas liquid chromatography (GLC) to determine the main constituents of essential oil according to Hoftman (1967). GLC was carried out as described by Guenther and Joseph (1978).

\section{Statistical analysis:}

The experiment design was complete randomized blocks design as included 19 treatments + control treatment with three replicates. Data were subjected to analysis of variance (ANOVA) by the general linear models (BLMS) procedure using (CoStat) statistical analysis system. Mean comparisons were performed using the least significant differences (L.S.D) method at significance level of $5 \%$ according to Gomez and Gomez (1984).

\section{RESULTS AND DISCUSSIONS}

\section{Effect of foliar spray with seaweed extract, chitosan and potassium silicate:}

\section{a. Vegetative growth and herb yield:}

Data presented in Tables (1, 2, 3 and 4) reveal that potassium silicate, seaweeds extract and chitosan at all concentrations significantly increased rosemary vegetative growth in terms of plant height, number of branches/plant as well plant fresh and dry weights in both growing seasons.

Plant height (cm), number of branches/plant, herb fresh and dry weights (g/plant) were increased with increasing foliar sprayed level of seaweed extract at 4 and $6 \mathrm{ml} / \mathrm{l}$ and chitosan up to 4 and $6 \mathrm{ml} / \mathrm{l}$ as well as potassium silicate up to $12 \mathrm{ml} / \mathrm{l}$ in 
Table 1. Effect of seaweed extract, chitosan and potassium silicate on plant height (cm)/plant of Rosmarinus officinalis L. for two cuts during 2017/ 2018 and 2018/2019 seasons.

\begin{tabular}{|c|c|c|c|c|}
\hline \multirow{3}{*}{ Treatments } & \multicolumn{4}{|c|}{ Plant height (cm) } \\
\hline & \multicolumn{2}{|c|}{ First season (2017/2018) } & \multicolumn{2}{|c|}{ Second season $(2018 / 2019)$} \\
\hline & $1^{\text {st }}$ cut & $2^{\text {nd }}$ cut & $1^{\text {st }}$ cut & $2^{\text {nd }}$ cut \\
\hline Control & 16.00 & 18.41 & 16.33 & 20.33 \\
\hline Sw. at $2 \mathrm{ml} / \mathrm{l}$ & 25.16 & 27.00 & 24.50 & 25.50 \\
\hline Sw. at $4 \mathrm{ml} / \mathrm{l}$ & 26.50 & 32.33 & 35.53 & 31.50 \\
\hline Sw. at $6 \mathrm{ml} / \mathrm{l}$ & 31.50 & 38.16 & 38.00 & 44.26 \\
\hline Chi. at $2 \mathrm{ml} / \mathrm{l}$ & 22.33 & 23.50 & 23.50 & 24.50 \\
\hline Chi. at $4 \mathrm{ml} / \mathrm{l}$ & 26.00 & 27.66 & 28.30 & 35.16 \\
\hline Chi. at $6 \mathrm{ml} / \mathrm{l}$ & 29.66 & 36.50 & 30.00 & 44.50 \\
\hline $\mathrm{KSi}$. at $6 \mathrm{ml} / \mathrm{l}$ & 22.00 & 24.50 & 25.50 & 29.00 \\
\hline KSi. at $9 \mathrm{ml} / \mathrm{l}$ & 32.16 & 32.50 & 31.50 & 37.33 \\
\hline $\mathrm{KSi}$. at $12 \mathrm{ml} / \mathrm{l}$ & 38.50 & 43.50 & 39.16 & 47.50 \\
\hline LSD 5\% & 2.2442 & 1.8762 & 3.1409 & 3.0495 \\
\hline
\end{tabular}

Sw.: seaweeds extract; Chi.: chitosan; KSi.: potassium silicate.

Table 2. Effect of seaweed extract, chitosan and potassium silicate on number of branches/plant of Rosmarinus officinalis L. for two cuts during 2017/ 2018 and $2018 / 2019$ seasons.

\begin{tabular}{|c|c|c|c|c|}
\hline \multirow{3}{*}{ Treatments } & \multicolumn{4}{|c|}{ Number of branches/plant } \\
\hline & \multicolumn{2}{|c|}{ First season (2017/2018) } & \multicolumn{2}{|c|}{ Second season $(2018 / 2019)$} \\
\hline & $1^{\text {st }}$ cut & $2^{\text {nd }}$ cut & $1^{\text {st }}$ cut & $2^{\text {nd }}$ cut \\
\hline Control & 15.08 & 20.00 & 22.00 & 25.00 \\
\hline Sw. at $2 \mathrm{ml} / \mathrm{l}$ & 21.50 & 24.33 & 26.10 & 30.16 \\
\hline Sw. at $4 \mathrm{ml} / \mathrm{l}$ & 25.50 & 31.00 & 31.50 & 35.50 \\
\hline Sw. at $6 \mathrm{ml} / \mathbf{l}$ & 30.33 & 35.80 & 35.00 & 39.00 \\
\hline Chi. at $2 \mathrm{ml} / \mathrm{l}$ & 21.00 & 23.16 & 22.33 & 28.50 \\
\hline Chi. at $4 \mathrm{ml} / \mathrm{l}$ & 24.00 & 26.66 & 23.00 & 35.00 \\
\hline Chi. at $6 \mathrm{ml} / \mathrm{l}$ & 27.80 & 31.16 & 27.50 & 37.50 \\
\hline $\mathrm{KSi}$. at $6 \mathrm{ml} / \mathrm{l}$ & 23.50 & 33.50 & 28.00 & 32.00 \\
\hline KSi. at $9 \mathrm{ml} / \mathrm{l}$ & 27.10 & 37.83 & 36.00 & 36.50 \\
\hline $\mathrm{KSi}$. at $12 \mathrm{ml} / \mathrm{l}$ & 34.50 & 46.16 & 43.50 & 49.83 \\
\hline LSD 5\% & 2.6491 & 2.6311 & 3.392 & 2.8949 \\
\hline
\end{tabular}

Sw.: seaweeds extract; Chi.: chitosan; KSi.: potassium silicate.

Table 3. Effect seaweed extract, chitosan and potassium silicate of on fresh weights plant (g) of Rosmarinus officinalis $L$. for two cuts during 2017/2018 and 2018/2019 seasons.

\begin{tabular}{|c|c|c|c|c|}
\hline \multirow{3}{*}{ Treatments } & \multicolumn{4}{|c|}{ Herb fresh weight (g/plant) } \\
\hline & \multicolumn{2}{|c|}{ First season (2017/2018) } & \multicolumn{2}{|c|}{ Second season $(2018 / 2019)$} \\
\hline & $1^{\text {st }}$ cut & $2^{\text {nd }}$ cut & $1^{\text {st }}$ cut & $2^{\text {nd }}$ cut \\
\hline Control & 19.66 & 23.15 & 24.35 & 23.60 \\
\hline Sw. at $2 \mathrm{ml} / \mathrm{l}$ & 24.90 & 27.33 & 28.02 & 31.14 \\
\hline Sw. at $4 \mathrm{ml} / \mathrm{l}$ & 28.23 & 32.00 & 36.90 & 42.39 \\
\hline Sw. at $6 \mathrm{ml} / \mathrm{l}$ & 35.35 & 38.60 & 46.11 & 50.71 \\
\hline Chi. at $2 \mathrm{ml} / \mathrm{l}$ & 21.80 & 26.50 & 26.70 & 33.80 \\
\hline Chi. at $4 \mathrm{ml} / \mathrm{l}$ & 24.40 & 30.80 & 34.83 & 36.68 \\
\hline Chi. at $6 \mathrm{ml} / \mathrm{l}$ & 32.63 & 37.70 & 37.31 & 47.76 \\
\hline KSi. at $6 \mathrm{ml} / \mathrm{l}$ & 25.40 & 28.20 & 28.62 & 36.89 \\
\hline KSi. at $9 \mathrm{ml} / \mathrm{l}$ & 29.60 & 37.00 & 38.98 & 40.93 \\
\hline $\mathrm{KSi}$. at $12 \mathrm{ml} / \mathrm{l}$ & 37.59 & 42.60 & 49.20 & 51.74 \\
\hline LSD 5\% & 2.4406 & 2.9255 & 2.6092 & 3.05117 \\
\hline
\end{tabular}

Sw.: seaweeds extract; Chi.: chitosan; KSi.: potassium silicate. 
Table 4. Effect of seaweed extract, chitosan and potassium silicate on dry weights plants (g) of Rosmarinus officinalis L. for two cuts during 2017/ 2018 and 2018/ 2019 seasons.

\begin{tabular}{|c|c|c|c|c|}
\hline \multirow{3}{*}{ Treatments } & \multicolumn{4}{|c|}{ Herb dry weight (g/plant) } \\
\hline & \multicolumn{2}{|c|}{ First season $(2017 / 2018)$} & \multicolumn{2}{|c|}{ Second season $(2018 / 2019)$} \\
\hline & $1^{\text {st }}$ cut & $2^{\text {nd }}$ cut & $1^{\text {st }}$ cut & $2^{\text {nd }}$ cut \\
\hline Control & 11.13 & 15.47 & 13.41 & 18.25 \\
\hline Sw. at $2 \mathrm{ml} / \mathrm{l}$ & 15.60 & 19.80 & 16.00 & 21.65 \\
\hline Sw. at $4 \mathrm{ml} / \mathrm{l}$ & 18.82 & 21.50 & 22.00 & 27.00 \\
\hline Sw. at $6 \mathrm{ml} / \mathrm{l}$ & 23.15 & 29.30 & 31.33 & 34.57 \\
\hline Chi. at $2 \mathrm{ml} / \mathrm{l}$ & 14.59 & 18.10 & 18.87 & 21.85 \\
\hline Chi. at $4 \mathrm{ml} / \mathrm{l}$ & 18.07 & 21.62 & 23.40 & 27.39 \\
\hline Chi. at $6 \mathrm{ml} / \mathrm{l}$ & 20.00 & 28.29 & 27.03 & 31.75 \\
\hline KSi. at $6 \mathrm{ml} / \mathrm{l}$ & 18.00 & 18.30 & 20.91 & 28.16 \\
\hline KSi. at $9 \mathrm{ml} / \mathrm{l}$ & 20.60 & 25.78 & 24.72 & 32.30 \\
\hline KSi. at $12 \mathrm{ml} / \mathrm{l}$ & 25.58 & 32.89 & 33.28 & 37.48 \\
\hline LSD 5\% & 2.2671 & 2.8502 & 1.7985 & 2.345 \\
\hline
\end{tabular}

Sw.: seaweeds extract; Chi.: chitosan; KSi.: potassium silicate.

both seasons and for the two cuts. These results were in harmony with the finding of El-Leithy et al. (2019) on Plectranthus amboinicus and Nasiroleslami and Safaridolatabad (2014) on dill as they reported that foliar application of seaweed increased vegetative growth. Also, the obtained results of chitosan are in agreement with those reported by Fawzy et al. (2012) and Ahmed (2015) on garlic and El-Miniawy et al. (2013) on strawberry. They showed that spraying plants with chitosan increased vegetative growth parameters compared to untreated plants. A number of possible mechanisms are proposed by which Si can increase resistance of plants against salinity stress. Hussein and Nesreen (2014) reported that addition of silicon as the nutrient reversed the salt inhibited mainly by reducing the Na uptake into the shoot. Bradbury and Ahmed (1990) on Prosopis juliflora, found that silicon application enhanced fresh matter yield of salt sensitive and salt tolerant genotypes under stressful conditions created by salt application.

It could be noticed that spraying rosemary with potassium silicate at $12 \mathrm{ml} / \mathrm{l}$ or seaweeds extract at $6 \mathrm{ml} / \mathrm{l}$ showed higher significant increases in all studied growth characters compared to control unsprayed during both seasons. Also, Abou ElYazied et al. (2012) mentioned that foliar application of seaweeds extract enhanced snap bean growth. Moreover, Kim et al. (2005) reported that chitosan has been shown to stimulate growth of sweet basil plants and Saif Eldeen et al. (2014) on globe artichoke plants attained similar results.

\section{b. Chemical constituents:}

\section{Photosynthetic pigments content:}

Data presented in Tables (5, 6, 7 and 8) showed chlorophyll a, b, carotenoids and total chlorophylls in fresh leaves of $R$. officinalis, L. plant foliar sprayed with seaweed extract, chitosan and potassium silicate, respectively.

In general, chlorophylls content in the fresh leaves of rosemary recorded a significant increase as a result of foliar sprayed seaweed extract levels comparing to control. The highest values of chlorophyll a (1.273,1.285, 1.280 and $1.288 \mathrm{mg} / \mathrm{g}$ f.w.) were obtained with using foliar seaweed extract at $6 \mathrm{~m} / \mathrm{l}$ in the two seasons, respectively compared to control values (0.990, 0.996, 0.995 and $0.999 \mathrm{mg} / \mathrm{g}$ f.w. in both cuts of both seasons, respectively). Chitosan levels at $6 \mathrm{~m} / \mathrm{l}$ gave the highest values of chlorophyll a (1.256, 1.261, 1.270 and $1.282 \mathrm{mg} / \mathrm{g} \mathrm{f.w.)}$ in both seasons, while the lowest values resulted from control plants (0.990, 0.996, 0.995 and $0.999 \mathrm{mg} / \mathrm{g}$ f.w, respectively). Chlorophyll a was increased with increasing potassium silicate levels in both seasons at $12 \mathrm{~m} / \mathrm{l}$ gave 
Table 5. Effect of seaweed extract, chitosan and potassium silicate on chlorophyll a $(\mathrm{mg} / \mathrm{g}$ f.w.) of Rosmarinus officinalis L. for two cuts during 2017/2018 and 2018/2019 seasons.

\begin{tabular}{|c|c|c|c|c|}
\hline \multirow{3}{*}{ Treatments } & \multicolumn{4}{|c|}{ Chlorophyll a (mg/g f.w.) } \\
\hline & \multicolumn{2}{|c|}{ First season (2017/2018) } & \multicolumn{2}{|c|}{ Second season $(2018 / 2019)$} \\
\hline & $1^{\text {st }}$ cut & $2^{\text {nd }}$ cut & $1^{\text {st }}$ cut & $2^{\text {nd }}$ cut \\
\hline Control & 0.990 & 0.996 & 0.995 & 0.999 \\
\hline Sw. at $2 \mathrm{ml} / \mathrm{l}$ & 1.130 & 1.143 & 1.175 & 1.181 \\
\hline Sw. at $4 \mathrm{ml} / \mathrm{l}$ & 1.235 & 1.247 & 1.240 & 1.245 \\
\hline Sw. at $6 \mathrm{ml} / \mathrm{l}$ & 1.273 & 1.285 & 1.280 & 1.288 \\
\hline Chi. at $2 \mathrm{ml} / \mathrm{l}$ & 1.150 & 1.157 & 1.094 & 1.112 \\
\hline Chi. at $4 \mathrm{ml} / \mathrm{l}$ & 1.230 & 1.239 & 1.202 & 1.215 \\
\hline Chi. at $6 \mathrm{ml} / \mathrm{l}$ & 1.256 & 1.261 & 1.270 & 1.282 \\
\hline KSi. at $6 \mathrm{ml} / \mathrm{l}$ & 1.305 & 1.315 & 1.309 & 1.317 \\
\hline $\mathrm{KSi}$. at $9 \mathrm{ml} / \mathrm{l}$ & 1.318 & 1.321 & 1.321 & 1.320 \\
\hline KSi. at $12 \mathrm{ml} / \mathrm{l}$ & 1.345 & 1.350 & 1.349 & 1.362 \\
\hline LSD $5 \%$ & 0.00365 & 0.00368 & 0.00489 & 0.00209 \\
\hline
\end{tabular}

Sw.: seaweeds extract; Chi.: chitosan; KSi.: potassium silicate.

Table 6. Effect of seaweed extract, chitosan and potassium silicate on chlorophyll b (mg/g f.w.) of Rosmarinus officinalis $L$. for two cuts during 2017/2018 and 2018/2019 seasons.

\begin{tabular}{|c|c|c|c|c|}
\hline \multirow{3}{*}{ Treatments } & \multicolumn{4}{|c|}{ Chlorophyll b (mg/g f.w.) } \\
\hline & \multicolumn{2}{|c|}{ First season (2017/2018) } & \multicolumn{2}{|c|}{ Second season $(2018 / 2019)$} \\
\hline & $1^{\text {st }}$ cut & $2^{\text {nd }}$ cut & $1^{\text {st }}$ cut & $2^{\text {nd }}$ cut \\
\hline Control & 0.200 & 0.212 & 0.261 & 0.270 \\
\hline Sw. at $2 \mathrm{ml} / \mathrm{l}$ & 0.298 & 0.309 & 0.290 & 0.298 \\
\hline Sw. at $4 \mathrm{ml} / \mathrm{l}$ & 0.366 & 0.375 & 0.361 & 0.372 \\
\hline Sw. at $6 \mathrm{ml} / \mathbf{l}$ & 0.376 & 0.380 & 0.381 & 0.395 \\
\hline Chi. at $2 \mathrm{ml} / \mathrm{l}$ & 0.285 & 0.291 & 0.287 & 0.294 \\
\hline Chi. at $4 \mathrm{ml} / \mathrm{l}$ & 0.328 & 0.226 & 0.324 & 0.338 \\
\hline Chi. at $6 \mathrm{ml} / \mathrm{l}$ & 0.370 & 0.379 & 0.369 & 0.379 \\
\hline $\mathrm{KSi}$. at $6 \mathrm{ml} / \mathrm{l}$ & 0.366 & 0.373 & 0.362 & 0.378 \\
\hline KSi. at $9 \mathrm{ml} / \mathrm{l}$ & 0.376 & 0.381 & 0.379 & 0.382 \\
\hline KSi. at $12 \mathrm{ml} / \mathrm{l}$ & 0.388 & 0.388 & 0.376 & 0.389 \\
\hline LSD $5 \%$ & 0.00389 & 0.00356 & 0.00553 & 0.00337 \\
\hline
\end{tabular}

Sw.: seaweeds extract; Chi.: chitosan; KSi.: potassium silicate.

Table 7. Effect of seaweed extract, chitosan and potassium silicate on carotenaids (mg/g f.w.) of Rosmarinus officinalis L. for two cuts during 2017/2018 and 2018/2019 seasons.

\begin{tabular}{|c|c|c|c|c|}
\hline \multirow{3}{*}{ Treatments } & \multicolumn{4}{|c|}{ Carotenoids (mg/g f.w.) } \\
\hline & \multicolumn{2}{|c|}{ First season } & \multicolumn{2}{|c|}{ Second season } \\
\hline & $1^{\text {st }}$ cut & $2^{\text {nd }}$ cut & $1^{\text {st }}$ cut & $2^{\text {nd }}$ cut \\
\hline Control & 0.181 & 0.110 & 0.170 & 0.117 \\
\hline Sw. at $2 \mathrm{ml} / \mathrm{l}$ & 0.260 & 0.162 & 0.267 & 0.167 \\
\hline Sw. at $4 \mathrm{ml} / \mathrm{l}$ & 0.369 & 0.280 & 0.297 & 0.288 \\
\hline Sw. at $6 \mathrm{ml} / \mathrm{l}$ & 0.438 & 0.305 & 0.320 & 0.312 \\
\hline Chi. at $2 \mathrm{ml} / \mathrm{l}$ & 0.253 & 0.140 & 0.238 & 0.152 \\
\hline Chi. at $4 \mathrm{ml} / \mathrm{l}$ & 0.365 & 0.210 & 0.355 & 0.216 \\
\hline Chi. at $6 \mathrm{ml} / \mathrm{l}$ & 0.432 & 0.359 & 0.398 & 0.369 \\
\hline KSi. at $6 \mathrm{ml} / \mathrm{l}$ & 0.294 & 0.220 & 0.211 & 0.228 \\
\hline KSi. at $9 \mathrm{ml} / \mathrm{l}$ & 0.380 & 0.210 & 0.299 & 0.219 \\
\hline KSi. at $12 \mathrm{ml} / \mathrm{l}$ & 0.410 & 0.390 & 0.375 & 0.304 \\
\hline LSD 5\% & 0.0308 & 0.0055 & 0.0038 & 0.0039 \\
\hline
\end{tabular}

Sw.: seaweeds extract; Chi.: chitosan; KSi.: potassium silicate. 
Table 8. Effect of seaweed extract, chitosan and potassium silicate on total chlorophylls of Rosmarinus officinalis L. for two cuts during 2017/2018 and 2018/2019 seasons.

\begin{tabular}{|c|c|c|c|c|}
\hline \multirow{3}{*}{ Treatments } & \multicolumn{4}{|c|}{ Total chlorophyll (mg/g f.w.) } \\
\hline & \multicolumn{2}{|c|}{ First season (2017/2018) } & \multicolumn{2}{|c|}{ Second season $(2018 / 2019)$} \\
\hline & $1^{\text {st }}$ cut & $2^{\text {nd }}$ cut & $1^{\text {st }}$ cut & $2^{\text {nd }}$ cut \\
\hline Control & 1.191 & 1.208 & 1.256 & 1.269 \\
\hline Sw. at $2 \mathrm{ml} / \mathrm{l}$ & 1.428 & 1.452 & 1.465 & 1.479 \\
\hline Sw. at $4 \mathrm{ml} / \mathrm{l}$ & 1.601 & 1.622 & 1.601 & 1.617 \\
\hline Sw. at $6 \mathrm{ml} / \mathrm{l}$ & 1.649 & 1.667 & 1.661 & 1.683 \\
\hline Chi. at $2 \mathrm{ml} / \mathrm{l}$ & 1.435 & 1.448 & 1.381 & 1.406 \\
\hline Chi. at $4 \mathrm{ml} / \mathrm{l}$ & 1.558 & 1.465 & 1.526 & 1.553 \\
\hline Chi. at $6 \mathrm{ml} / \mathrm{l}$ & 1.626 & 1.637 & 1.639 & 1.661 \\
\hline $\mathrm{KSi}$. at $6 \mathrm{ml} / \mathbf{l}$ & 1.671 & 1.691 & 1.671 & 1.695 \\
\hline $\mathrm{KSi}$. at $9 \mathrm{ml} / \mathrm{l}$ & 1.694 & 1.702 & 1.701 & 1.702 \\
\hline $\mathrm{KSi}$. at $12 \mathrm{ml} / \mathrm{l}$ & 1.733 & 1.738 & 1.725 & 1.751 \\
\hline LSD $5 \%$ & 0.0035 & 0.0039 & 0.0043 & 0.0034 \\
\hline
\end{tabular}

Sw.: seaweeds extract; Chi.: chitosan; KSi.: potassium silicate.

$1.345,1.350,1.349$ and $1.362 \mathrm{mg} / \mathrm{g}$ f.w. which were the best values in both seasons, respectively. The superiority was to this above-mentioned treatment when compared with control and other treatments.

Chlorophyll b was increased with increasing foliar sprayed seaweed extract levels. The best results of chlorophyll b (0.376, 0.382, 0.381 and $0.395 \mathrm{mg} / \mathrm{g}$ f.w.) were recorded by foliar sprayed seaweed extract level of $6 \mathrm{~m} / \mathrm{l}$ in the first and second seasons, respectively. Chlorophyll b increased with using chitosan level as recorded the best results $(0.370,0.379,0.369$ and $0.379 \mathrm{mg} / \mathrm{g}$ f.w.) from chitosan levels at $6 \mathrm{~m} / \mathrm{l}$ in the first and second seasons, respectively. The lowest values were obtained from control plants $(0.200,0.212$, 0.261 and $0.270 \mathrm{mg} / \mathrm{g}$ f.w. in both cuts for both seasons, respectively).Chlorophyll b was increased with using potassium silicate, the best results $(0.376,0.387,0.376$ and $0.398 \mathrm{mg} / \mathrm{g}$ f.w.) were recorded by potassium silicate at $12 \mathrm{ml} / \mathrm{l}$ in the first and second seasons, respectively.

Total content of chlorophylls was the highest for the plants sprayed with chitosan at $6 \mathrm{ml} / \mathrm{l}(1.626,1.640,1.636$ and $1.659 \mathrm{mg} / \mathrm{g}$ f.w.) while the least values resulted from control (1.252, 1.268, 1.1256 and 1.269 mg/g f.w.) in both season for both cuts.
The total content of chlorophyll was the highest for sprayed plants with potassium silicate at $12 \mathrm{ml} / \mathrm{l}(1.733,1.748,1.716$ and $1.751 \mathrm{mg} / \mathrm{g}$ f.w.) while the least values resulted from control (1.252, 1.268, 1.256 and $1.269 \mathrm{mg} / \mathrm{g} \mathrm{f.w.)}$ in both seasons for both cuts. These results are in harmony with finding of Gharib et al. (2014) who showed that foliar application of seaweed on rosemary plant was positive active on microelement content and photosynthetic pigments compared to the untreated plant. Also, this result is in accordance with the results obtained by Pise and Sabale (2010) on fenugreek plant, Nasiroleslami and Safaridolatabad (2014) on dill and El-Leithy et al. (2019) on Plectuanthus amboinicus (Lour).

Carotenoids contents were increased with increasing foliar sprayed seaweed extract levels. The best results were obtained from foliar sprayed seaweed extract level at $6 \mathrm{~m} / \mathrm{l}$ which gave 2.008, 2.012, 2.212 and $2.129 \mathrm{mg} / \mathrm{g} \mathrm{f.w}$. for both cuts in the first and second seasons, respectively, while the less carotenoids content values were obtained with control (1.410, 1.417, 1.470 and $1.481 \mathrm{mg} / \mathrm{g} \mathrm{f.w.,} \mathrm{in} \mathrm{both} \mathrm{seasons} \mathrm{and}$ cuts respectively). Carotenoids increased with increasing chitosan level. The best results were obtained from chitosan at $6 \mathrm{ml} / \mathrm{l}$ which gave 1.859, 1.869, 1.698 and 1.879 $\mathrm{mg} / \mathrm{g}$ f.w. for both cuts in the first and 


\section{A.A. Waly et al.}

second seasons, respectively. Carotenoids also, increased as the highest level of potassium silicate $(12 \mathrm{~m} / \mathrm{l})$ was applied, which gave 1.990, 1.904, 2.675 and $2.681 \mathrm{mg} / \mathrm{g}$ f.w. for both cuts in the first and second seasons, respectively.

The results of chitosan are in harmony with those reported by Chookhongkha et al. (2012). Also, with potassium silicate are in harmony with Al-Sobhi et al. (2005) on Calotropts procera they reported that high levels of salinization gave a significant decrease in the contents of Chlorophyll a, b and carotenoids.

\section{Nitrogen percentage in the leaves:}

Data illustrated in Table (9) showed that, the percentages of nitrogen in dry rosemary leaves was increased by increasing seaweed extract levels. The highest values of nitrogen percentage in the two cuts of both seasons $(1.400,1.420,1.390$ and $1.440 \%)$ were obtained by the plants received the highest rate of foliar sprayed seaweed extract (6 $\mathrm{m} / \mathrm{l})$. The percentages of nitrogen in dry rosemary leaves were increased by increasing the chitosan levels (Table, 9). The highest values of nitrogen percentage in the two cuts in both seasons $(1.370,1.390,1.380$ and $1.390 \%$ ) were obtained from chitosan level of $6 \mathrm{~m} / \mathrm{l}$. Also, increasing potassium silicate rate led to increase the percentages of nitrogen in dry leaves. The highest values of nitrogen percentage in the two cuts of both seasons (1.900, 1.930, 1.910 and 1.940\%) were obtained by the plants which received the highest rate of potassium silicate $(12 \mathrm{~m} / \mathrm{l}$ water). The superiority was to this abovementioned treatment when compared with control and other treatments. In this regard, percentage of nitrogen in control plants were $1.190,1.200,1.210$ and $1.230 \%$ in the two cuts of both seasons, respectively.

\section{Phosphorus percentage in the leaves:}

As shown in Table (10) the percentages of phosphorus in dry rosemary leaves were increased by increasing the sprayed seaweed extract level. The highest values of phosphorus percentage $(0.336,0.386,0.369$ and $0.389 \%$ ) were obtained by the plants which received the highest level $(6 \mathrm{~m} / \mathrm{l})$. Increasing chitosan levels led to increase the percentage of phosphorus in dry leaves. The highest values of phosphorus percentage $(0.289,0.291,0.299$ and $0.340 \%)$ were obtained in the plants which received the highest level of chitosan $(6 \mathrm{~m} / \mathrm{l})$. The percentage of phosphorus in dry leaves were increased by increasing the potassium silicate rates. The highest values of phosphorus percentage $(0.218,0.329,0.325$ and $0.345 \%$ ) were obtained by the plants which received the highest rate of potassium silicate $(12 \mathrm{~m} / \mathrm{l})$, when compared with control and other treatments, whereas such percentages in control plants were 0.245 , $0.251,0.252$ and $0.256 \%$ in the two cuts of both seasons, respectively.

\section{Potassium percentage in the leaves:}

Data in Table (11) showed that, percentage of potassium in dry leaves was increased by increasing the seaweed extract rates. The rate of $6 \mathrm{~m} / \mathrm{l}$ recorded a significant increase in this regard compared with control. The percentage of potassium in dry leaves was obtained as 1.400 and $1.490 \%$ for the first and second cuts, respectively in the first season and 1.440 and $1.520 \%$ for the first and second cuts, respectively in the second one.

The percentage of potassium in dry leaves was increased by increasing the chitosan rate. Chitosan at $6 \mathrm{~m} / \mathrm{l}$ recorded a significant increase in this regard compared with control. The percentage of potassium in dry leaves was obtained as $1.300 \%$ for the first cut, $2.930 \%$ for the second cut in the first season and 1.340 and $2.970 \%$ for the first and second cuts in the second season, respectively. The percentage of potassium in dry leaves was increased by increasing the potassium silicate rate as 9 and $12 \mathrm{~m} / \mathrm{l}$ recorded a significant increase in this regard compared with control and other treatments. The percentage of potassium in dry leaves was obtained as 1.810 and $2.760 \%$ for the first cut, 1.860 and $2.930 \%$ for the second cut in the first season and 1.820 and $2.800 \%$ 
Table 9. Effect of seaweed extract, chitosan and potassium silicate on nitrogen (\% of d.w.) of Rosmarinus officinalis L. for two cuts during 2017/2018 and 2018/2019 seasons.

\begin{tabular}{|c|c|c|c|c|}
\hline \multirow{3}{*}{ Treatments } & \multicolumn{4}{|c|}{ Nitrogen (\% d.w.) } \\
\hline & \multicolumn{2}{|c|}{ First season (2017/2018) } & \multicolumn{2}{|c|}{ Second season $(2018 / 2019)$} \\
\hline & $1^{\text {st }}$ cut & $2^{\text {nd }}$ cut & $1^{\text {st }}$ cut & $2^{\text {nd }}$ cut \\
\hline Control & 1.190 & 1.200 & 1.210 & 1.230 \\
\hline Sw. at $2 \mathrm{ml} / \mathrm{l}$ & 1.290 & 1.310 & 1.300 & 1.330 \\
\hline Sw. at $4 \mathrm{ml} / \mathrm{l}$ & 1.370 & 1.390 & 1.360 & 1.390 \\
\hline Sw. at $6 \mathrm{ml} / \mathrm{l}$ & 1.400 & 1.420 & 1.390 & 1.440 \\
\hline Chi. at $2 \mathrm{ml} / \mathrm{l}$ & 1.310 & 1.280 & 1.310 & 1.320 \\
\hline Chi. at $4 \mathrm{ml} / \mathrm{l}$ & 1.330 & 1.340 & 1.350 & 1.370 \\
\hline Chi. at $6 \mathrm{ml} / \mathrm{l}$ & 1.370 & 1.390 & 1.380 & 1.390 \\
\hline $\mathrm{KSi}$. at $6 \mathrm{ml} / \mathbf{l}$ & 1.720 & 1.760 & 1.730 & 1.770 \\
\hline $\mathrm{KSi}$. at $9 \mathrm{ml} / \mathrm{l}$ & 1.810 & 1.860 & 1.820 & 1.880 \\
\hline $\mathrm{KSi}$. at $12 \mathrm{ml} / \mathrm{l}$ & 1.900 & 1.930 & 1.910 & 1.940 \\
\hline LSD 5\% & 0.00279 & 0.00336 & 0.00305 & 0.00294 \\
\hline
\end{tabular}

Sw.: seaweeds extract; Chi.: chitosan; KSi.: potassium silicate.

Table 10. Effect of seaweed extract, chitosan and potassium silicate on phosphorus (\% o d.w.) of Rosmarinus officinalis L. for two cuts during 2017/2018 and 2018/201! seasons.

\begin{tabular}{|c|c|c|c|c|}
\hline \multirow{3}{*}{ Treatments } & \multicolumn{4}{|c|}{ Phosphorus (\% d.w.) } \\
\hline & \multicolumn{2}{|c|}{ First season (2017/2018) } & \multicolumn{2}{|c|}{ Second season $(2018 / 2019)$} \\
\hline & $1^{\text {st }}$ cut & $2^{\text {nd }}$ cut & $1^{\text {st }}$ cut & $2^{\text {nd }}$ cut \\
\hline Control & 0.045 & 0.051 & 0.052 & 0.056 \\
\hline Sw. at $2 \mathrm{ml} / \mathrm{l}$ & 0.076 & 0.085 & 0.082 & 0.091 \\
\hline Sw. at $4 \mathrm{ml} / \mathrm{l}$ & 0.080 & 0.089 & 0.087 & 0.095 \\
\hline Sw. at $6 \mathrm{ml} / \mathrm{l}$ & 0.122 & 0.130 & 0.133 & 0.137 \\
\hline Chi. at $2 \mathrm{ml} / \mathrm{l}$ & 0.055 & 0.070 & 0.063 & 0.079 \\
\hline Chi. at $4 \mathrm{ml} / \mathrm{l}$ & 0.092 & 0.099 & 0.099 & 0.102 \\
\hline Chi. at $6 \mathrm{ml} / \mathrm{l}$ & 0.102 & 0.118 & 0.110 & 0.120 \\
\hline $\mathrm{KSi}$. at $6 \mathrm{ml} / \mathrm{l}$ & 0.208 & 0.221 & 0.210 & 0.225 \\
\hline $\mathrm{KSi}$. at $9 \mathrm{ml} / \mathrm{l}$ & 0.215 & 0.227 & 0.220 & 0.229 \\
\hline $\mathrm{KSi}$. at $12 \mathrm{ml} / \mathrm{l}$ & 0.218 & 0.239 & 0.225 & 0.245 \\
\hline LSD 5\% & 0.00337 & 0.00388 & 0.00275 & 0.00349 \\
\hline
\end{tabular}

Sw.: seaweeds extract; Chi.: chitosan; $\mathrm{KSi}$.: potassium silicate.

Table 11. Effect of seaweed extract, chitosan and potassium silicate on potassium (\% d.w.) of Rosmarinus officinalis $L$. for two cuts during 2017/2018 and 2018/2019 seasons.

\begin{tabular}{|c|c|c|c|c|}
\hline \multirow{3}{*}{ Treatments } & \multicolumn{4}{|c|}{ Potassium (\% d.w.) } \\
\hline & \multicolumn{2}{|c|}{ First season (2017/2018) } & \multicolumn{2}{|c|}{ Second season $(2018 / 2019)$} \\
\hline & $1^{\text {st }}$ cut & $2^{\text {nd }}$ cut & $1^{\text {st }}$ cut & $2^{\text {nd }}$ cut \\
\hline Control & 1.170 & 1.210 & 0.210 & 0.220 \\
\hline Sw. at $2 \mathrm{ml} / \mathrm{l}$ & 1.320 & 1.250 & 1.290 & 1.380 \\
\hline Sw. at $4 \mathrm{ml} / \mathrm{l}$ & 1.380 & 1.480 & 1.420 & 1.500 \\
\hline Sw. at $6 \mathrm{ml} / \mathrm{l}$ & 1.400 & 1.490 & 1.440 & 1.520 \\
\hline Chi. at $2 \mathrm{ml} / \mathrm{l}$ & 1.190 & 2.350 & 1.230 & 2.370 \\
\hline Chi. at $4 \mathrm{ml} / \mathrm{l}$ & 1.290 & 2.680 & 1.330 & 2.720 \\
\hline Chi. at $6 \mathrm{ml} / \mathrm{l}$ & 1.300 & 2.930 & 1.340 & 2.970 \\
\hline $\mathrm{KSi}$. at $6 \mathrm{ml} / \mathrm{l}$ & 2.350 & 2.430 & 2.370 & 2.460 \\
\hline KSi. at $9 \mathrm{ml} / \mathrm{l}$ & 2.500 & 2.680 & 2.550 & 2.720 \\
\hline $\mathrm{KSi}$ at $12 \mathrm{ml} / \mathrm{l}$ & 2.760 & 2.930 & 2.800 & 2.970 \\
\hline LSD 5\% & 0.0490 & 0.0371 & 0.0337 & 0.0327 \\
\hline
\end{tabular}

Sw.: seaweeds extract; Chi.: chitosan; KSi.: potassium silicate. 


\section{A.A. Waly et al.}

and 1.880 and $2.970 \%$ in the second one for 9 and $12 \mathrm{ml} / \mathrm{l}$, respectively.

These results are in harmony with those mentioned by Gharib et al. (2014) on rosemary they showed that foliar application of seaweed on rosemary plant was positively active on microelement content and photosynthetic pigments compared to the untreated plant. Similar findings were also obtained by Fawzy et al. (2012) on garlic who found that treated plants with chitosan increased $\mathrm{N}, \mathrm{P}$ and $\mathrm{K}$ contents in leaves than unsprayed ones. Ahmed (2015) indicated that sprayed garlic plants with chitosan at 4 and $6 \mathrm{ml} / \mathrm{l}$ recorded the highest $\mathrm{N}, \mathrm{P}$ and $\mathrm{K}$ contents of leaves and bulbs than untreated plants.

Exogenous applications of elicitor compounds as chitosan (i.e., deacylated chitin) induces mineral nutrition. Pise and Sabale (2010) showed that carbohydrate, and proteins, free amino acids, polyphenols and nitrogen content increased in seaweed treated plants. In the same direction, there was significant effect due to seaweed extract (sea force1) on chlorophyll, carbohydrates, nitrogen, phosphorous and potassium in leaves of artichoke plants (Saif Eldeen, 2014).

\section{Total carbohydrates in leaves:}

Results in Table (12) revealed that the total carbohydrates percentage in rosemary leaves were significantly increased by increasing sprayed foliar seaweed extract rates under each level in the both seasons as $6 \mathrm{ml} / \mathrm{l}$ recorded the highest values of total carbohydrate (30.72 and $32.35 \%$ in the first season and 34.35 and $35.71 \%$ in the second one for the two cuts, respectively). The increase in carbohydrates (\%) of rosemary as a result of using seaweed extract may be due to the higher energy caused by these treatments in synthesis of biochemical metabolites for the plant. El-Leithy et al. (2019) found that using the seaweed extract significantly increased all the studied characters of chemical composition of Plectuanthus amboinicus (Lour).
The results revealed that increasing chitosan level significantly led to increase total carbohydrates percentage in rosemary leaves in both cuts of both seasons. Chitosan at $6 \mathrm{~m} / \mathrm{l}$ recorded the highest values of total carbohydrates (28.33 and 30.21\%) in the first season and 30.19 and $33.53 \%$ in the second one for both cuts. The increase in carbohydrates content of rosemary as a result of using chitosan may be due to the higher energy caused by these treatments in synthesis of biochemical metabolites for the plant. Ahmed (2015) on garlic indicated that sprayed garlic plants with chitosan at the highest rates gave the best results for increasing mineral content and total carbohydrates in cloves at harvest than control treatment.

The results revealed that total carbohydrates percentage in rosemary leaves were significantly increased by increasing potassium silicate levels in both seasons as $12 \mathrm{ml} / \mathrm{l}$ recorded the highest values of total carbohydrate when compared with control and other treatments as recorded 34.60 and $35.45 \%$ in the first season and 35.85 and $38.65 \%$ in the second one, for both cuts. The increase in carbohydrates content of rosemary as a result of using potassium silicate may be due to the higher energy caused by these treatments in synthesis of biochemical metabolites for the plant. Also, foliar application of potassium silicate enhanced plant growth as reported by Diwate (2018) on sweet orange, El-Leithy et al. (2019) on Plectranthus amboinicus and Gharib et al. (2014) on rosemary.

\section{c. Essential oil percentage in the herb:}

The two levels of sprayed foliar seaweed extract gradually increased essential oil percentage in both seasons (Table, 13). These increments were statistically significant as compared to control plants, except for the lower concentration of seaweed extract at $2 \mathrm{ml} / \mathrm{l}$ for the first cut in the two studied seasons. The most effective treatments were the medium and higher concentrations (4 and $6 \mathrm{ml} / \mathrm{l}$ ). The highest values of the essential oil percentage ranged 
Table 12. Effect of seaweeds, chitosan and potassium silicate on carbohydrates (\%) of Rosmarinus officinalis $L$. for two cuts during two seasons.

\begin{tabular}{|c|c|c|c|c|}
\hline \multirow{3}{*}{ Treatments } & \multicolumn{4}{|c|}{ Total carbohydrates (\%) } \\
\hline & \multicolumn{2}{|c|}{ First season (2017/2018) } & \multicolumn{2}{|c|}{ Second season $(2018 / 2019)$} \\
\hline & $1^{\text {st }}$ cut & $2^{\text {nd }}$ cut & $1^{\text {st }}$ cut & $2^{\text {nd }}$ cut \\
\hline Control & 18.62 & 21.48 & 20.13 & 23.54 \\
\hline Sw. at $2 \mathrm{ml} / \mathrm{l}$ & 24.36 & 25.51 & 26.52 & 27.77 \\
\hline Sw. at $4 \mathrm{ml} / \mathrm{l}$ & 26.43 & 28.54 & 29.52 & 30.46 \\
\hline Sw. at $6 \mathrm{ml} / \mathrm{l}$ & 30.72 & 32.35 & 34.35 & 35.71 \\
\hline Chi. at $2 \mathrm{ml} / \mathrm{l}$ & 22.48 & 23.34 & 23.55 & 26.16 \\
\hline Chi. at $4 \mathrm{ml} / \mathrm{l}$ & 25.35 & 27.51 & 26.53 & 28.73 \\
\hline Chi. at $6 \mathrm{ml} / \mathrm{l}$ & 28.14 & 30.21 & 30.19 & 33.53 \\
\hline $\mathrm{KSi}$. at $6 \mathrm{ml} / \mathbf{I}$ & 25.45 & 27.85 & 25.18 & 29.18 \\
\hline $\mathrm{KSi}$. at $9 \mathrm{ml} / \mathrm{l}$ & 28.50 & 31.81 & 32.39 & 33.45 \\
\hline $\mathrm{KSi}$. at $12 \mathrm{ml} / \mathrm{l}$ & 34.60 & 35.45 & 35.85 & 38.65 \\
\hline LSD 5\% & 1.8355 & 1.9322 & 1.7053 & 1.8320 \\
\hline
\end{tabular}

Sw.: seaweeds extract; Chi.: chitosan; KSi.: potassium silicate.

Table 13. Effect of seaweeds, chitosan and potassium silicate on essential oil percentage of Rosmarinus officinalis $L$. for two cuts during two seasons.

\begin{tabular}{|c|c|c|c|c|}
\hline \multirow{3}{*}{ Treatments } & \multicolumn{4}{|c|}{ Essential oil (\%) } \\
\hline & \multicolumn{2}{|c|}{ First season $(2017 / 2018)$} & \multicolumn{2}{|c|}{ Second season $(2018 / 2019)$} \\
\hline & $1^{\text {st }}$ cut & $2^{\text {nd }}$ cut & $1^{\text {st }}$ cut & $2^{\text {nd }}$ cut \\
\hline Control & 0.21 & 0.23 & 0.25 & 0.27 \\
\hline Sw. at $2 \mathrm{ml} / \mathrm{l}$ & 0.25 & 0.32 & 0.29 & 0.35 \\
\hline Sw. at $4 \mathrm{ml} / \mathrm{l}$ & 0.34 & 0.43 & 0.37 & 0.40 \\
\hline Sw. at $6 \mathrm{ml} / \mathrm{l}$ & 0.37 & 0.48 & 0.43 & 0.46 \\
\hline Chi. at $2 \mathrm{ml} / \mathrm{l}$ & 0.24 & 0.26 & 0.26 & 0.33 \\
\hline Chi. at $4 \mathrm{ml} / \mathrm{l}$ & 0.31 & 0.38 & 0.31 & 0.38 \\
\hline Chi. at $6 \mathrm{ml} / \mathrm{l}$ & 0.35 & 0.44 & 0.41 & 0.42 \\
\hline $\mathrm{KSi}$. at $6 \mathrm{ml} / \mathrm{l}$ & 0.26 & 0.28 & 0.27 & 0.38 \\
\hline KSi. at $9 \mathrm{ml} / \mathrm{l}$ & 0.37 & 0.39 & 0.35 & 0.43 \\
\hline $\mathrm{KSi}$. at $12 \mathrm{ml} / \mathrm{l}$ & 0.45 & 0.48 & 0.45 & 0.50 \\
\hline LSD 5\% & 0.0325 & 0.0229 & 0.0249 & 0.0355 \\
\hline
\end{tabular}

Sw.: seaweeds extract; Chi.: chitosan; KSi.: potassium silicate.

between $0.37, \quad 0.48, \quad 0.43$ and $0.46 \%$ compared to the control $(0.21,0.23,0.25$ and $0.26 \%$ ) in both seasons. The increase in the essential oil percentage when rosemary plants received the high level of seaweed extract may be attributed to the higher energy in synthesis of biochemical metabolites as a result to applied seaweed extract. These results are in agreement with those mentioned by Nasiroleslami and Safaridolatabad (2014) on dill. Gharib et al. (2014) on rosemary reported that foliar application of seaweed significantly increased rosemary oil percentage compared to the untreated plant. Karthikeyan and Shanmugam (2015) found that the highest oil content obtained from foliar application of seaweed on peanut and sunflower compared to other applications or control plant (untreated). El-Leithy et al. (2019) found that using the seaweed extract significantly increased all the studied characters of essential oil and chemical composition of Plectuanthus amboinicus (Lour).

The three levels of chitosan gradually increased essential oil percentage in both seasons. These increments were statistically significant as compared to unsprayed plants, except for the lower concentration of chitosan $(2 \mathrm{~m} / \mathrm{l})$ for the first cut in the two studied seasons. The most effective treatments were the medium $(4 \mathrm{ml} / \mathrm{l})$ and the highest concentration $(6 \mathrm{ml} / \mathrm{l})$. The highest values of the essential oil percentage ranged between $0.35, \quad 0.44, \quad 0.41$ and $0.42 \%$ compared to the control $(0.21,0.23,0.25$ and $0.27 \%$ ) in the both seasons. 


\section{A.A. Waly et al.}

The increase in the essential oil percentage when rosemary plants received the high level of chitosan may be attributed to the higher energy in synthesis of biochemical metabolites as a result to applied chitosan. These results are in harmony with those mentioned in by Kim et al. (2005) who reported that essential oil compounds were increased with application of chitosan at $0.5 \%$ in sweet basil.

The three levels of potassium silicate gradually increased essential oil percentage in both seasons. These increments were statistically significant as compared to control plants, except for lower concentration of potassium silicate $(6 \mathrm{ml} / \mathrm{l})$ for the first cut in the two studied seasons. The most effective treatments were the medium $(9 \mathrm{ml} / \mathrm{l})$ and higher concentrations $(12 \mathrm{~m} / \mathrm{l})$. The highest values of the essential oil percentage ranged between $0.45,0.48$, 0.45 and $0.50 \%$ compared to the control $(0.21,0.23,0.25$ and $0.27 \%)$ in the both seasons.

The increase in the essential oil percentage when rosemary plants received the high level of potassium silicate may be attributed to the higher energy in synthesis of biochemical metabolites as a result to applied potassium silicate.

\section{Effect of combination treatments between seaweed extract and chitosan:}

Foliar spraying with chitosan and seaweeds extract combinations significantly affected all growth characters (plant height, number of branches/plant, herb fresh weight/plant and dry weight of herb/plant) in both seasons in the two cuts (Table, 14). However, the previous studies proved that

Table 14. Effect of combination treatments between seaweed extract and chitosan on vegetative growth of Rosmarinus officinalis $L$. for two cuts during 2017/2018 and $2018 / 2019$ seasons.

\begin{tabular}{|c|c|c|c|c|c|c|c|c|c|}
\hline \multicolumn{2}{|c|}{ Treatments } & \multicolumn{2}{|c|}{ Plant height (cm) } & \multicolumn{2}{|c|}{$\begin{array}{c}\text { No. of } \\
\text { branches/plant }\end{array}$} & \multicolumn{2}{|c|}{ Plant f.w. (g) } & \multicolumn{2}{|c|}{ Plant d.w. (g) } \\
\hline $\begin{array}{l}\mathrm{Sw} . \\
\mathrm{ml} / \mathrm{l}\end{array}$ & $\begin{array}{l}\text { Chi. } \\
\mathrm{ml} / \mathrm{l}\end{array}$ & $1^{\text {st }}$ cut & $2^{\text {nd }}$ cut & $1^{\text {st }}$ cut & $2^{\text {nd }}$ cut & $1^{\text {st }}$ cut & $2^{\text {nd }}$ cut & $1^{\text {st }}$ cut & $2^{\text {nd }}$ cut \\
\hline \multicolumn{10}{|c|}{ First season $2017 / 2018$} \\
\hline $\mathbf{0}$ & $\mathbf{0}$ & 16.0 & 18.4 & 15 & 20 & 19.6 & 23.1 & 11.1 & 15.4 \\
\hline 2 & 2 & 28.3 & 33.5 & 28 & 33 & 38.1 & 40.3 & 24.7 & 25.4 \\
\hline 2 & 4 & 32.3 & 35.8 & 31 & 35 & 41.1 & 44.3 & 26.1 & 28.4 \\
\hline 2 & 6 & 35.7 & 38.2 & 34 & 36 & 43.1 & 45.3 & 28.1 & 33.8 \\
\hline 4 & 2 & 39.5 & 41.5 & 37 & 38 & 46.1 & 47.4 & 31.2 & 33.5 \\
\hline 4 & 4 & 44.2 & 46.8 & 42 & 43 & 52.1 & 55.4 & 35.2 & 38.5 \\
\hline 4 & 6 & 47.3 & 49.2 & 45 & 47 & 56.1 & 59.4 & 36.2 & 40.6 \\
\hline 6 & 2 & 42.6 & 43.5 & 39 & 41 & 49.2 & 52.5 & 33.3 & 34.6 \\
\hline 6 & 4 & 48.6 & 51.8 & 46 & 47 & 58.2 & 64.5 & 37.3 & 39.6 \\
\hline 6 & 6 & 53.3 & 55.2 & 48 & 50 & 64.2 & 65.5 & 38.3 & 42.7 \\
\hline \multicolumn{2}{|c|}{ LSD 5\% } & 1.845 & 1.769 & 3.726 & 1.664 & 3.162 & 3.307 & 3.301 & 3.757 \\
\hline \multicolumn{10}{|c|}{ Second season $2018 / 2019$} \\
\hline $\mathbf{0}$ & $\mathbf{0}$ & 16.3 & 20.3 & 22 & 25 & 24.3 & 23.6 & 13.4 & 18.2 \\
\hline 2 & 2 & 29.2 & 31.2 & 34 & 36 & 40.1 & 41.4 & 27.5 & 28.6 \\
\hline 2 & 4 & 33.5 & 35.5 & 37 & 39 & 42.2 & 44.3 & 32.5 & 34.4 \\
\hline 2 & 6 & 37.8 & 48.0 & 39 & 43 & 45.3 & 47.6 & 34.0 & 36.0 \\
\hline 4 & 2 & 38.2 & 39.1 & 42 & 45 & 47.3 & 49.4 & 34.0 & 35.0 \\
\hline 4 & 4 & 46.5 & 48.4 & 45 & 47 & 53.3 & 56.4 & 37.0 & 38.0 \\
\hline 4 & 6 & 49.8 & 51.7 & 49 & 53 & 58.4 & 63.7 & 39.7 & 41.0 \\
\hline 6 & 2 & 41.2 & 44.3 & 45 & 46 & 51.4 & 54.6 & 35.0 & 37.0 \\
\hline 6 & 4 & 52.0 & 57.3 & 49 & 54 & 62.4 & 66.3 & 45.1 & 43.0 \\
\hline 6 & 6 & 55.8 & 59.6 & 52 & 56 & 65.5 & 70.3 & 43.8 & 45.0 \\
\hline \multicolumn{2}{|c|}{ LSD 5\% } & 3.421 & 3.063 & 3.319 & 2.972 & 3.442 & 2.791 & 3.788 & 3.824 \\
\hline
\end{tabular}

Sw.: seaweeds extract; Chi.: chitosan. 
seaweeds and/or chitosan can, directly or indirectly, influence the physiological activities of the plants (Kamal and Ghanem, 2011 and Shehata et al., 2012).

The combination between spraying seaweeds at $6 \mathrm{ml} / \mathrm{l}+$ chitosan at $6 \mathrm{ml} / \mathrm{l}$ treatments significantly produced the highest plants (53.3, 55.2, 55.8 and $59.6 \mathrm{~cm}$ for the first and second seasons and its two cuts, respectively) compared with control which gave the shortest plants as recorded 16.0 and 18.4 in the first season and 16.3 and $20.3 \mathrm{~cm}$ in the second season for both cuts.

Data of foliar spraying of chitosan and seaweeds extract levels combinations showed that, chlorophyll a, b, carotenoids and the total content of chlorophylls in fresh leaves of $R$. officinalis L. plant significantly were affected at concentration of seaweeds at $6 \mathrm{ml} / \mathrm{l}+$ chitosan $6 \mathrm{ml} / \mathrm{l}$ in the two seasons for the two cuts (Table, 15). These results were in harmony with Saif Eldeen et al. (2014) on Globe artichoke.

Data in Table (16) showed that combination between spraying with seaweeds at $6 \mathrm{ml} / \mathrm{l}+$ chitosan at $6 \mathrm{ml} / \mathrm{l}$ significantly produced the highest essential oil percentage (0.48 and $0.49 \%)$ and $(0.51$ and $0.54 \%$ ) for the first and second seasons and its two cuts compared with control which gave the lowest values (0.21 and $0.23 \%$ in the first season and 0.25 and $0.27 \%$ in the second one for both cuts).

The results in Table (16) revealed that total carbohydrates percentage in rosemary leaves were significantly increased by increasing spraying combination between seaweeds at $6 \mathrm{ml} / \mathrm{l}+$ chitosan at $6 \mathrm{ml} / \mathrm{l}$ treatments in both seasons. The highest values of total carbohydrates were 27.53 and

Table 15. Effect of combination treatments between seaweed extract and chitosan or chlorophylls a, b, carotenoids and total chlorophylls (mg/g f.w.) o Rosmarinus officinalis $L$. for two cuts during 2017/2018 and 2018/2019 seasons.

\begin{tabular}{|c|c|c|c|c|c|c|c|c|c|}
\hline \multicolumn{2}{|c|}{ Treatments } & \multicolumn{2}{|c|}{ Chlorophyll a } & \multicolumn{2}{|c|}{ Chlorophyll b } & \multicolumn{2}{|c|}{ Carotenoids } & \multicolumn{2}{|c|}{ Total chlorophylls } \\
\hline $\begin{array}{l}\text { Sw. } \\
\mathrm{ml} / \mathrm{l}\end{array}$ & $\begin{array}{l}\text { Chi. } \\
\mathrm{ml} / \mathrm{l}\end{array}$ & $1^{\text {st }}$ cut & $2^{\text {nd }}$ cut & $1^{\text {st }}$ cut & $2^{\text {nd }}$ cut & $1^{\text {st }}$ cut & $2^{\text {nd }}$ cut & $1^{\text {st }}$ cut & $2^{\text {nd }}$ cut \\
\hline \multicolumn{10}{|c|}{ First season (2017/2018) } \\
\hline $\mathbf{0}$ & $\mathbf{0}$ & 0.96 & 0.98 & 0.20 & 0.21 & 0.181 & 0.110 & 1.19 & 1.20 \\
\hline 2 & 2 & 1.28 & 1.29 & 0.38 & 0.39 & 0.230 & 0.205 & 1.67 & 1.69 \\
\hline 2 & 4 & 1.37 & 1.38 & 0.43 & 0.44 & 0.350 & 0.263 & 1.81 & 1.84 \\
\hline 2 & 6 & 1.38 & 1.38 & 0.44 & 0.45 & 0.210 & 0.319 & 1.82 & 1.84 \\
\hline 4 & 2 & 1.35 & 1.36 & 0.45 & 0.46 & 0.380 & 0.288 & 1.80 & 1.82 \\
\hline 4 & 4 & 1.38 & 1.38 & 0.45 & 0.46 & 0.290 & 0.299 & 1.84 & 1.86 \\
\hline 4 & 6 & 1.39 & 1.39 & 0.46 & 0.47 & 0.285 & 0.305 & 1.85 & 1.87 \\
\hline 6 & 2 & 1.39 & 1.41 & 0.42 & 0.48 & 0.447 & 0.489 & 1.87 & 1.89 \\
\hline 6 & 4 & 1.43 & 1.44 & 0.48 & 0.49 & 0.559 & 0.567 & 1.91 & 1.93 \\
\hline 6 & 6 & 1.46 & 1.47 & 0.48 & 0.49 & 0.600 & 0.620 & 1.95 & 1.96 \\
\hline \multicolumn{2}{|c|}{ LSD 5\% } & 0.0039 & 0.0034 & 0.0035 & 0.0034 & 0.0341 & 0.0043 & 0.0033 & 0.0036 \\
\hline \multicolumn{10}{|c|}{ Second season $(2018 / 2019)$} \\
\hline $\mathbf{0}$ & $\mathbf{0}$ & 0.95 & 0.99 & 0.26 & 0.27 & 0.170 & 0.117 & 1.25 & 1.26 \\
\hline 2 & 2 & 1.27 & 1.28 & 0.38 & 0.39 & 0.252 & 0.167 & 1.67 & 1.68 \\
\hline 2 & 4 & 1.27 & 1.28 & 0.43 & 0.44 & 0.359 & 0.269 & 1.81 & 1.73 \\
\hline 2 & 6 & 1.34 & 1.35 & 0.46 & 0.45 & 0.327 & 0.338 & 1.82 & 1.80 \\
\hline 4 & 2 & 1.36 & 1.37 & 0.43 & 0.45 & 0.245 & 0.353 & 1.80 & 1.82 \\
\hline 4 & 4 & 1.38 & 1.39 & 0.45 & 0.46 & 0.390 & 0.399 & 1.84 & 1.86 \\
\hline 4 & 6 & 1.38 & 1.37 & 0.46 & 0.48 & 0.221 & 0.132 & 1.85 & 1.85 \\
\hline 6 & 2 & $1.37 \mathrm{~b}$ & 1.40 & 0.47 & 0.40 & 0.282 & 0.294 & 1.87 & 1.78 \\
\hline 6 & 4 & 1.45 & 1.46 & 0.48 & 0.49 & 0.474 & 0.485 & 1.91 & 1.96 \\
\hline 6 & 6 & 1.46 & 1.48 & 0.48 & 0.50 & 0.599 & 0.610 & 1.95 & 1.99 \\
\hline \multicolumn{2}{|c|}{ LSD 5\% } & 0.0182 & 0.0173 & 0.0199 & 0.0437 & 0.0045 & 0.0033 & 0.0355 & 0.0628 \\
\hline
\end{tabular}

Sw.: seaweeds extract; Chi.: chitosan. 
Table 16. Effect of combination treatments between seaweed extract and chitosan on essential oil percentage and carbohydrates (\%) of Rosmarinus officinalis $\mathbf{L}$. for two cuts during two seasons.

\begin{tabular}{|c|c|c|c|c|c|c|c|c|c|}
\hline \multicolumn{2}{|c|}{ Treatments } & \multicolumn{4}{|c|}{ Essential oil (\%) } & \multicolumn{4}{|c|}{ Total carbohydrates (\%) } \\
\hline \multirow{2}{*}{$\begin{array}{l}\mathrm{Sw} . \\
\mathrm{ml} / \mathrm{l}\end{array}$} & \multirow{2}{*}{$\begin{array}{l}\text { Chi. } \\
\mathrm{ml} / \mathrm{l}\end{array}$} & \multicolumn{2}{|c|}{ First season } & \multicolumn{2}{|c|}{ Second season } & \multicolumn{2}{|c|}{ First season } & \multicolumn{2}{|c|}{ Second season } \\
\hline & & $1^{\text {st }}$ cut & $2^{\text {nd }}$ cut & $1^{\text {st }}$ cut & $2^{\text {nd }}$ cut & $1^{\text {st }}$ cut & $2^{\text {nd }}$ cut & $1^{\text {st }}$ cut & $2^{\text {nd }}$ cut \\
\hline $\mathbf{0}$ & $\mathbf{0}$ & 0.21 & 0.23 & 0.25 & 0.27 & 18.62 & 21.48 & 20.13 & 23.54 \\
\hline 2 & 2 & 0.37 & 0.38 & 0.39 & 0.39 & 19.50 & 21.40 & 21.43 & 23.61 \\
\hline 2 & 4 & 0.38 & 0.42 & 0.40 & 0.43 & 21.50 & 22.40 & 23.32 & 25.57 \\
\hline 2 & 6 & 0.41 & 0.43 & 0.44 & 0.46 & 23.00 & 24.30 & 24.90 & 27.62 \\
\hline 4 & 2 & 0.40 & 0.41 & 0.42 & 0.43 & 24.40 & 25.50 & 27.10 & 28.35 \\
\hline 4 & 4 & 0.44 & 0.43 & 0.44 & 0.46 & 22.40 & 24.60 & 25.10 & 27.13 \\
\hline 4 & 6 & 0.45 & 0.47 & 0.49 & 0.50 & 26.20 & 28.57 & 28.10 & 29.16 \\
\hline 6 & 2 & 0.42 & 0.44 & 0.43 & 0.45 & 24.00 & 25.50 & 26.20 & 28.51 \\
\hline 6 & 4 & 0.47 & 0.49 & 0.49 & 0.52 & 26.60 & 27.40 & 28.35 & 31.68 \\
\hline 6 & 6 & 0.48 & 0.49 & 0.51 & 0.54 & 27.53 & 29.39 & 30.46 & 32.42 \\
\hline \multicolumn{2}{|c|}{ LSD 5\% } & 0.0168 & 0.0153 & 0.0187 & 0.0148 & 2.253 & 3.367 & 3.408 & 3.0387 \\
\hline
\end{tabular}

Sw.: seaweeds extract; Chi.: chitosan.

$29.39 \%$ in the first season and 30.46 and $32.42 \%$ in the second one compared with control (18.62, 21.48, 20.13 and 23.54\% in both seasons and its cuts, respectively). These results were in harmony with finding of Olle and Schnug (2016).

The essential oil components (\%) of Rosmarinus officinalis L. plant was influenced by the combination between foliar extract seaweed and chitosan in the first cut at the second season as shown in Table (17) and illustrated in Fig. (1). The components were $\alpha$-pinene, limonene, camphene, camphor, $\alpha$-terpineole, 1.8cineole, borneol, bornyl-acetate, eugenol, $\beta$ pinene, $\beta$-caryophyllene. The highest value of the main components was $\alpha$-pinene, camphor and 1.8-cineole. The Spraying combination between seaweeds at $6 \mathrm{ml} / \mathrm{l}+$ chitosan at $6 \mathrm{ml} / \mathrm{l}$ treatment gave $99.98 \%$, while the spraying combination between seaweeds at $4 \mathrm{ml} / \mathrm{l}+$ chitosan at $6 \mathrm{ml} / \mathrm{l}$ treatment gave $98.08 \%$ compared to spraying seaweeds at $2 \mathrm{ml} / \mathrm{l}$ treatment as gave

Table 17. Essential oil components (\%) of Rosmarinus officinalis, L. plant as affected by the combination between foliar extract seaweed and chitosan in the $1^{\text {st }}$ cut in the second season.

\begin{tabular}{|c|c|c|c|c|c|c|c|c|c|c|c|c|}
\hline \multirow{3}{*}{ Components (\%) } & \multicolumn{12}{|c|}{ Treatments } \\
\hline & \multicolumn{4}{|c|}{ Sw. 2} & \multicolumn{4}{|c|}{ Sw. 4} & \multicolumn{4}{|c|}{ Sw. 6} \\
\hline & Cont. & Chi. 2 & Chi. 4 & Ch. 6 & Cont. & Chi. 2 & Chi. 4 & Chi. 6 & Cont. & Chi. 2 & Ch. 4 & Chi. 6 \\
\hline$\alpha$-pinene & 1.31 & 4.54 & 4.91 & 7.11 & 4.31 & 5.65 & 1.43 & 13.68 & 5.61 & 3.11 & 12.36 & 6.81 \\
\hline Limonene & 4.59 & 2.61 & 3.24 & 3.77 & 1.52 & 1.66 & 5.11 & 20.68 & 2.46 & 4.88 & 19.36 & 18.39 \\
\hline CamI & 1.41 & 1.13 & 3.44 & _ & 13.75 & 20.24 & 1.53 & 2.56 & 5.47 & 1.89 & 4.55 & 8.34 \\
\hline Camphor & 13.82 & 11.35 & 12.97 & 14.61 & 9.84 & 9.71 & 19.06 & 18.89 & 12.65 & 16.72 & 16.39 & 8.01 \\
\hline$\alpha$-Terpineole & 10.82 & 9.52 & 9.85 & 5.21 & 6.39 & 8.14 & 13.42 & 11.04 & 2.19 & 10.99 & 10.67 & 9.41 \\
\hline 1.8-cineole & 1.63 & 5.23 & 4.96 & - & 5.34 & 1.91 & - & 1.47 & 1.43 & 7.51 & 2.81 & 19.31 \\
\hline Borneol & 5.67 & 8.31 & 5.87 & - & 11.03 & 5.31 & 15.34 & 9.97 & 1.54 & 4.72 & 8.38 & 22.76 \\
\hline Bornyl-a & 4.71 & 18.75 & 15.97 & 22.14 & 2.86 & 2.01 & 17.91 & 13.76 & - & 13.81 & 14.24 & 4.42 \\
\hline Eugenol & 13.3 & 10.28 & 11.15 & 11.24 & 1.76 & 3.04 & - & 4.83 & 19.38 & 3.56 & 3.43 & 2.51 \\
\hline$\beta$-pinene & 1.79 & 4.01 & 8.79 & 12.38 & 2.49 & 16.74 & 19.27 & - & 9.72 & 18.3 & 1.04 & - \\
\hline$\beta$-Caryophyllene & 1.95 & 4.01 & 4.46 & 11.03 & 3.36 & 4.46 & - & 1.12 & 12.32 & 4.97 & 3.12 & - \\
\hline Total components & 60.99 & 79.71 & 85.61 & 87.46 & 62.65 & 78.84 & 93.07 & 98.08 & 72.76 & 90.47 & 96.96 & 99.98 \\
\hline
\end{tabular}

Cont.: control.

Sw. 2, 4 and 6: seaweeds extract at 2, 4 and $6 \mathrm{ml} / \mathrm{l}$.

Chi. 2, 4 and 6: chitosan at 2, 4 and $6 \mathrm{ml} / \mathrm{l}$. 


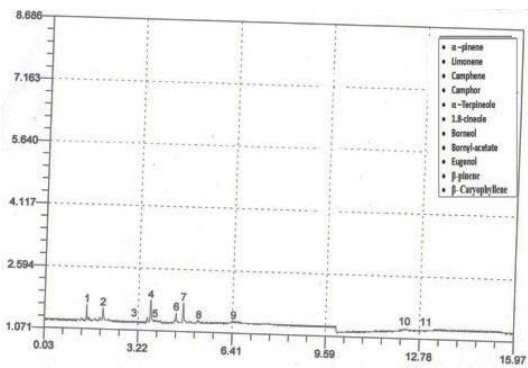

Control

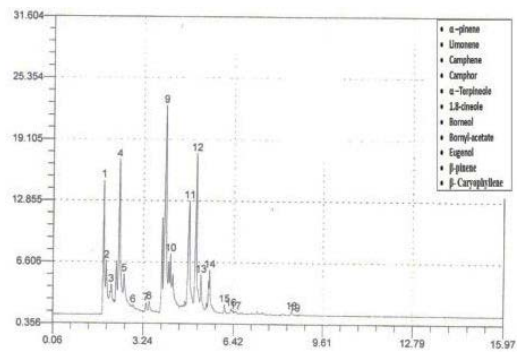

Sw. $2 \mathrm{ml} / \mathrm{l}+$ Chi. $6 \mathrm{ml} / \mathrm{l}$

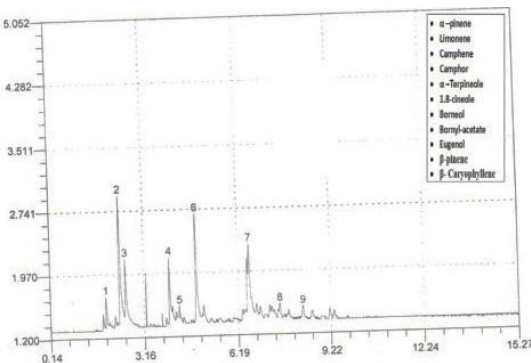

Sw. $6 \mathrm{ml} / \mathrm{l}$

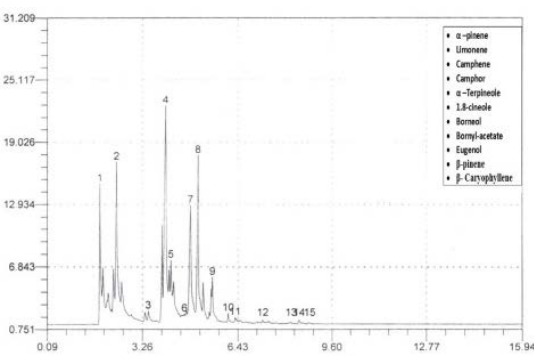

Sw. $4 \mathrm{ml} / \mathrm{l}+$ Chi. $6 \mathrm{ml} / \mathrm{l}$

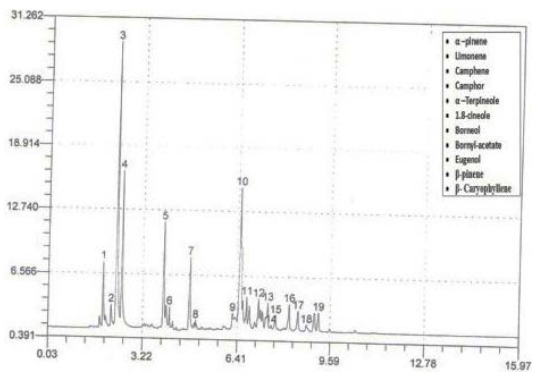

Sw. $4 \mathrm{ml} / \mathrm{l}+$ Chi. $2 \mathrm{ml} / \mathrm{l}$

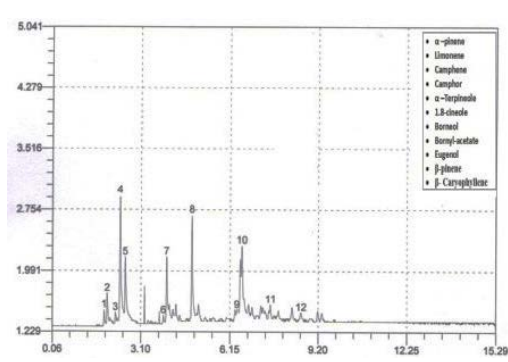

Sw. $4 \mathrm{ml} / \mathrm{l}+$ Chi. $4 \mathrm{ml} / \mathrm{l}$

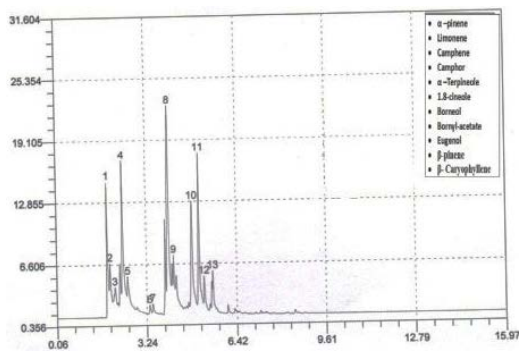

Sw. $6 \mathrm{ml} / \mathrm{l}+$ Chi. $6 \mathrm{ml} / \mathrm{l}$

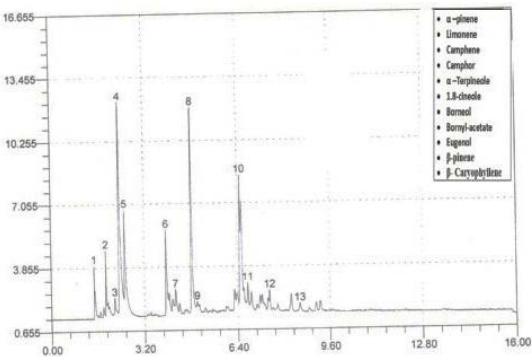

Sw. $6 \mathrm{ml} / \mathrm{l}+$ Chi. $2 \mathrm{ml} / \mathrm{l}$

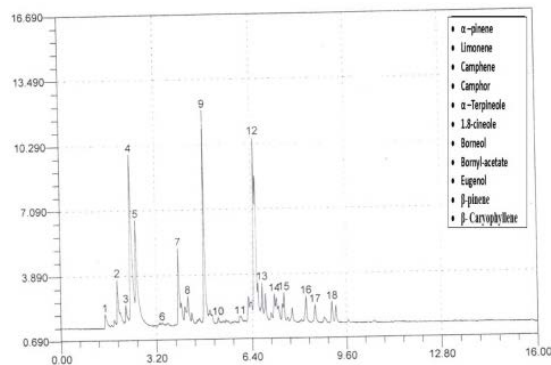

Sw. $2 \mathrm{ml} / \mathrm{l}$

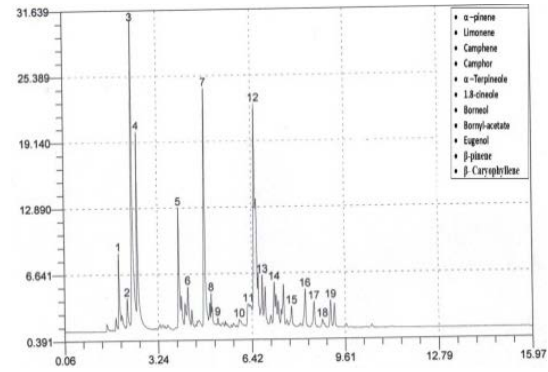

Sw. $4 \mathrm{ml} / \mathrm{l}$

Fig. 1. G.L.C. chromatogram analysis of Rosmarinus officinalis L. oil constituents as affected by combination treatments between seaweed extract and chitosan foliar spraying. 


\section{A.A. Waly et al.}

$60.99 \%$. These results were in harmony with those of Kim et al. (2005) on Ocimum basilicum L., Lei et al. (2011) on Artemisia annua and Bistgani et al. (2016) on Thymus daenensis.

Analysis by GLC of essential oil samples was done for the first cut at the second season. In general, under all treatments of seaweed, chitosan and their combinations markedly increased the percentage of most essential oil components extracted from rosemary plants. Seaweed at $4 \mathrm{ml} / \mathrm{l}$ combined with chitosan at $1 \mathrm{ml} / \mathrm{l}$ gave the highest values of camphor, $\alpha$-terpineole, bornyl-acetate and $\beta$-pinene. While, seaweed at $4 \mathrm{ml} / \mathrm{l}$ combined with chitosan at $6 \mathrm{ml} / \mathrm{l}$ gave the highest values of 1.8-cineole and borneol.

Data of foliar spraying with chitosan and seaweeds extract levels combinations showed that $\mathrm{N}, \mathrm{P}$ and $\mathrm{K} \%$ were greatly affected by all treatments compared with the control in the two seasons and two cuts (Table, 18). The significant increments in the obtained characters over control may be attributed to its effects on enhancing ion uptake (Marschner, 2013).

\section{CONCLUSION}

From the results it could be concluded that the application of seaweed extract and chitosan on rosemary had positive effects separately or combining together and significantly increased the vegetative growth, yield (herb) and percentage of essential oil. The best rate of using them was a result of using at the highest concentrations of seaweed extract and chitosan (seaweed extract $6 \mathrm{ml} / \mathrm{l}$ water + chitosan $6 \mathrm{ml} / \mathrm{l}$ water). From that, it can therefore be recommended that the application of bio-fertilities is useful and important to increase the quality and yield of production in rosemary plants.

Table 18. Effect of combination treatments between seaweed extract chitosan on nitrogen, phosphorus and potassium (\% d.w.) of Rosmarinus officinalis L. for two cuts during $2017 / 2018$ and $2018 / 2019$ seasons.

\begin{tabular}{|c|c|c|c|c|c|c|c|}
\hline \multicolumn{2}{|c|}{ Treatments } & \multicolumn{2}{|c|}{ N\% } & \multicolumn{2}{|c|}{$\mathbf{P \%}$} & \multicolumn{2}{|c|}{ K\% } \\
\hline $\begin{array}{l}\text { Sw. } \\
\mathrm{ml} / \mathrm{l}\end{array}$ & $\begin{array}{l}\text { Chi. } \\
\mathrm{ml} / \mathrm{l}\end{array}$ & $1^{\text {st }}$ cut & $2^{\text {nd }}$ cut & $1^{\text {st }}$ cut & $2^{\text {nd }}$ cut & $1^{\text {st }}$ cut & $2^{\text {nd }}$ cut \\
\hline \multicolumn{8}{|c|}{ First season (2017/2018) } \\
\hline $\mathbf{0}$ & $\mathbf{0}$ & 1.19 & 1.20 & 0.045 & 0.051 & 1.17 & 1.21 \\
\hline 2 & 2 & 1.49 & 1.48 & 0.145 & 0.169 & 1.52 & 1.61 \\
\hline 2 & 4 & 1.50 & 1.51 & 0.158 & 0.177 & 1.57 & 1.63 \\
\hline 2 & 6 & 1.51 & 1.54 & 0.178 & 0.190 & 1.58 & 1.69 \\
\hline 4 & 2 & 1.81 & 1.96 & 0.191 & 0.203 & 1.67 & 1.78 \\
\hline 4 & 4 & 2.50 & 2.52 & 0.202 & 0.219 & 2.54 & 2.63 \\
\hline 4 & 6 & 2.54 & 2.59 & 0.216 & 0.223 & 2.57 & 2.69 \\
\hline 6 & 2 & 1.92 & 1.98 & 0.205 & 0.215 & 1.77 & 1.80 \\
\hline 6 & 4 & 2.57 & 2.66 & 0.225 & 0.234 & 2.63 & 2.73 \\
\hline 6 & 6 & 2.63 & 2.68 & 0.231 & 0.242 & 2.84 & 2.98 \\
\hline \multicolumn{2}{|c|}{ L S D $0.05 \%$} & 0.0036 & 0.0038 & 0.0321 & 0.0035 & 0.0034 & 0.0035 \\
\hline \multicolumn{8}{|c|}{ Second season $(2018 / 2019)$} \\
\hline $\mathbf{0}$ & $\mathbf{0}$ & 1.21 & 1.23 & 0.052 & 0.056 & 0.21 & 0.22 \\
\hline 2 & 2 & 1.43 & 1.94 & 0.154 & 0.172 & 1.21 & 1.65 \\
\hline 2 & 4 & 1.51 & 1.52 & 0.167 & 0.183 & 1.56 & 1.67 \\
\hline 2 & 6 & 1.51 & 1.54 & 0.185 & 0.199 & 1.61 & 1.73 \\
\hline 4 & 2 & 1.81 & 1.97 & 0.199 & 0.210 & 1.65 & 1.82 \\
\hline 4 & 4 & 2.51 & 2.53 & 0.209 & 0.221 & 1.71 & 2.67 \\
\hline 4 & 6 & 2.55 & 2.59 & 0.221 & 0.228 & 2.58 & 2.75 \\
\hline 6 & 2 & 1.97 & 1.98 & 0.215 & 0.226 & 2.67 & 1.85 \\
\hline 6 & 4 & 2.57 & 2.66 & 0.231 & 0.242 & 2.67 & 2.77 \\
\hline 6 & 6 & 2.64 & 2.68 & 0.239 & 0.248 & 2.87 & 2.99 \\
\hline \multicolumn{2}{|c|}{ LSD 5\% } & 0.0036 & 0.0040 & 0.0036 & 0.0034 & 0.0034 & 0.0040 \\
\hline
\end{tabular}

Sw.: seaweeds extract; Chi.: chitosan. 


\section{REFERENCES}

Abou-Baker, A.H.; Abd-Eladl, M. and Abbas, M.M. (2011). Use of silicate and different cultivation practices in alleviating salt stress effect on bean plants. Australian J. Basic and Applied Sci., 5(9):769-781.

Abou El-Yazied, A.; El-Gizawy, A.M.; Ragab, M.I. and Hamed, E.S. (2012). Effect of seaweed extracts and compost treatments on growth, yield and quality of snap bean. Journal of American Science, 8:1-20.

Ahmed, M.E.M. (2015). Response of garlic plants (Allium sativum L.) to foliar application of some bio-stimulants. Egypt. J. Hort., 42(1):613-625.

Al-Sobhi, O.A.; Al-Zahrani, H.S. and AlAhmadi, S.B. (2005). Effect of salinity on chlorophyll and carbohydrate contents of Calotropis procera seedlings. Scientific Journal of King Faisal Univ. (Basic and Applied Sciences), 7(1):105115.

Bistgani, Z.F; Siadat S.A.; Bakhshandeh, A; Pirbaluti, A.G. and Hashemi M. (2016). Influence of chitosan concentration on morpho- physiological traits, essential oil and phenolic content under different fertilizers application in Thymus daenensis. Journal of Herbal Drugs, 7(2):117-125.

Bradbury, M. and Ahmed, R. (1990). The effect of silicon on the growth of Prosopis julifora growing in saline soil. Plant and Soil, 125: 71-74.

British Pharmacopoeia (2000). The Pharmaceutical Press 17 Bloomsburg, Square. W.C.I. London.

Castro, G.T.; Avelelas, F.P. and Leandro, S. (2016). Chitosan seed soaking: germination and growth of Coriandrum sativum and Solanum lycopersicum. Front. Mar. Sci. Conference Abstract: IMMR, International Meeting on Marine Research, FMARS, 125 p.
Chookhongkha, N.; Miyagawa S.; Jirakiattikul Y. and Photchanachai S. (2012). Chilli growth and seed productivity as affected by chitosan. International Conference on Agriculture Technology and Food Sciences, (ICATFS) Nov. 17-18, pp: 146-149.

El-Leithy, A.S.; El-Attar, A.B.E.; ElGhadban, E.A.E. and Abdel-Ghani, N.M. (2019). Effect of salinity, seaweed extract and salicylic acid on growth, essential oil and chemical composition of Plectranthus amboinicus (Lour). Journal Bioscience Research, 16(1):118-133.

El-Miniawy, S.M.; Ragab, M.E.; Youssef, S.M. and Metwally, A.A. (2013). Response of strawberry plants to foliar spraying of chitosan. Res. J. Agric. and Biol. Sci., 9(6): 366-372.

Fawzy, Z.F.; El-Shal, Z.S.; Yunsheng, L.; Zhu, O. and Sawan, O.M. (2012). Response of garlic (Allium sativum L.) plants to foliar spraying of some biostimulants under sandy soil condition. J. App. Sci. Res., 8(2):770-776.

Gharib, F.; Zeid, I.; Salem, O. and Ahmed, E. (2014). Effects of Sargassum latifolium extract on growth, oil content and enzymatic activities of rosemary plants under salinity stress. Life Sci. J., 11(10):933-945.

Gomez, K.A. and Gomez, A.A. (1984). Statistical Procedures for Agricultural Research. John Willey and Sons, Second Edition, New York, 680 p.

Guenther, Z. and Joseph, S. (1978). Handbook Series in Chromatography. GRC Press Inc.

Hadrami, A.E.; Adam, L.R.; Hadrami, I.E. and Daayf, F. (2010). Chitosan in plant protection. Mar. Drugs., 8:968-987.

Hadwiger, L.A. (2013). Multiple effects of chitosan on plant systems: Solid science or hype. Plant Sci., 20(8):42- 49.

Herbert, D.; Philips, P.J. and Strange, R.E. (1971). Determination of total 


\section{A.A. Waly et al.}

carbohydrates Methods in Mierobiology. Academic Press, London and New York, 5B, 58:209-344.

Hoftman, E. (1967). Chromatoraphy, Reinhold publ. corp., $2^{\text {nd }}$. Ed. pp: 208515.

Hussein, M.M. and Nesreen, H.A.B. (2014). Growth and mineral status of moringa plants as affected by silicate and salicylic acid under salt stress. Journal of Applied Sciences Research, 3(2):163-177.

Jackson, M.L. (1967). Soil Chemical Analysis. Prentica Hall Inc., Engle weed Cliffs, N.J.

Kamal, A.M. and Ghanem, K.M. (2011). Response of Cape gooseberry plants (Physalis peruviana L.) to some organic amendments and foliar spray with chitosan. J. Plant Production, Mansoura Univ., 2(12):1741-1759.

Karthikeyan, K. and Shanmugam, M. (2015). Yield and oil content of peanut (var. TMV-7) and sunflower (var. Co-2) applied with bio-stimulant AQUASAP. manufactured from seaweed, African J. of Agric. Res., 10(25):2537-2543.

Kim, H.J.; Chen, F.; Wang, X. and Rajapakse, N.C. (2005). Effect of chitosan on the biological properties of sweet basil (Ocimum basilicum L.). J. Agric. Food Chem., 53(9):696-701.

Lei, G.; Ma, D.; Pu. G.; Qiu, X.; ZhigaoDu, Z.; Wang, H.; Li, G.; HechunYe, H. and Liu, B. (2011). Foliar application of chitosan activates artemisinin biosynthesis in Artemisia annua L. Industrial Crops and Products, 33:176182.

Magen, H. (2004). Potassium in fertigation systems. International Potash Institute (IPI), 5 ${ }^{\text {th }}$ Fertigation Training Course, Boading, AUH, June 2004.

Mahdavi, B. (2013). Seed germination and growth responses of Isabgol (Plantago ovata Forsk) to chitosan and salinity.
International Journal of Agriculture and Crop Sciences., 5(10):10841088.

Marschner, H. (2013). Mineral Nutrition of Higher Plants, $3^{\text {th }}$ Ed. Academic Press, Harcourt Brace and Company, Publishers. London, New York and Tokyo, 864 p.

Mazumdar, B.C. and Majumder, K. (2003). Methods on Physic-Chemical Analysis of Fruits. Daya Publishing House, Delhi, India. 110-035.

Murphy, J.S. and Reilly, J.P. (1962). A modified single solution method for the determination of phosphate in natural water. Chemical Analysis Acta, 27:3136.

Nasiroleslami, E. and Safaridolatabad, S. (2014). The comparison of organic and biologic fertilizers effects on growth and essential oil of dill (Anethum graveolens L.). International Journal of Biosciences, 5(7):65-74.

Piper, O.S. (1947). Soil and Plant Analysis. Inter. Sci. Publishers. New York, pp: 213-217.

Pise, N. and Sabale, A. (2010). Effect of seaweed concentrates on growth and biochemical constituents of Trigonella foenum-graecum L. J. Phytology, 2(4): 50-56.

Saif Eldeen, U.M.; Shokr, M.M.B. and El Shotoury, R.S. (2014). Effect of foliar spray with seaweeds extract and chitosan on earliness and productivity of globe artichoke. J. Plant Production, Mansoura Univ., 5(7):1197-1207.

Shehata, S.A.; Fawzy, Z.F. and El-Ramady, H.R. (2012). Response of cucumber plants to foliar application of chitosan and yeast under greenhouse conditions. Aust. J. Basic and Appl. Sci., 6(4):63-71.

Smirnoff, N. (1995). Antioxidant systems and plant response to the environment. In: Smirnoff N, ed. Environmen and Plant Metabolism, Flexibility and 
Acclimation. Oxford: Bios Scientific Pub-lashers, p: 217-243.

Simon, J.E.; Chadwick, A.F. and Cracker, L.E. (1984). The scientific literature on selected herbs and medicinal plants of the temperate zone. Arch. Int. Med., 148:3639.

Wand, S.Y. and Galletta, G.J. (1998). Foliar application of potassium silicate induces metabolic changes in strawberry plants. J. Plant Nutr., 21(1):157-167.

Wang, M.; Zheng, Q.; Shen, Q. and Guo, S. (2013). The critical role of potassium in plant stress response. Inter. J. Molecular Sci., 14(4):7370-7390.

Wettestein, V.D. (1957). Chlorophyll-Lethal under submikroskopische, Formwechsel der Plastiden. Exp. Cell Res., 12(3):427506.

Wilde, S.A.; Corey, R.B.; Lyer, J.G. and Voigt, G.K. (1985). Soil and Plant Analysis for Tree Culture, $3^{\text {rd }}$ ed. Oxford and IBM Publishing Co., New Delhi, India, p: 529-546.

$$
\begin{aligned}
& \text { تأثير الرش الورقى بمستخلص الطحالب البحرية والشيتوزان وسليكات البوتاسيوم على نبات } \\
& \text { الحصالبان فى الارض البحر الرملية }
\end{aligned}
$$

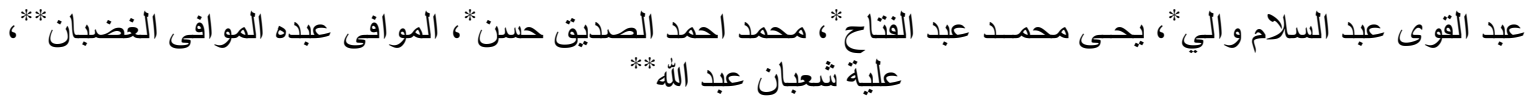

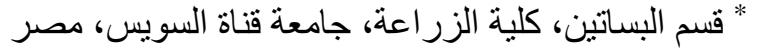

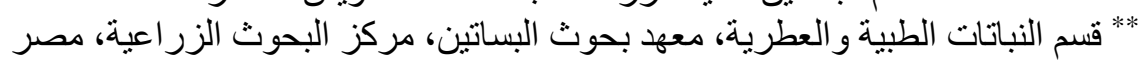

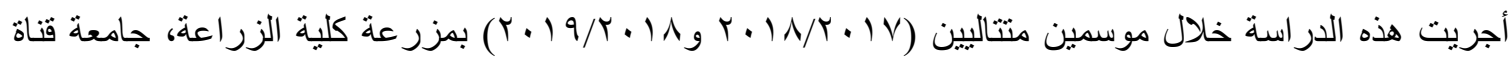

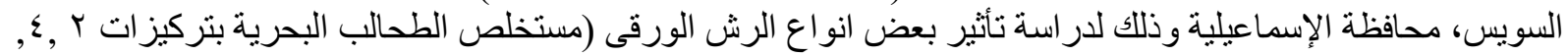

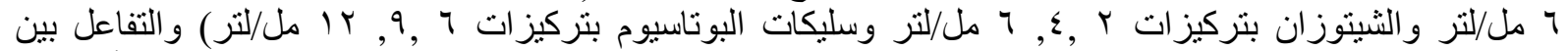

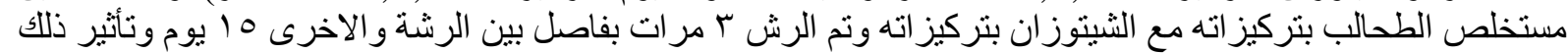

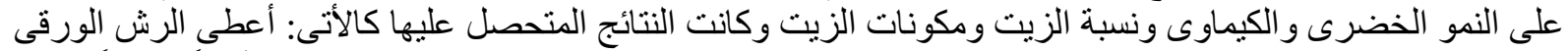

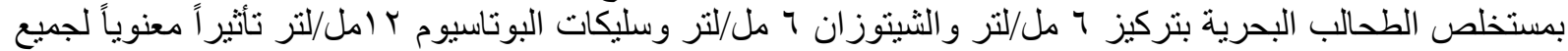

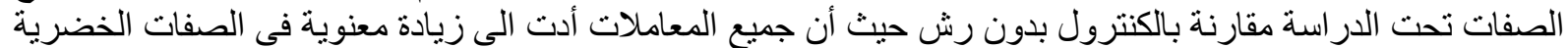

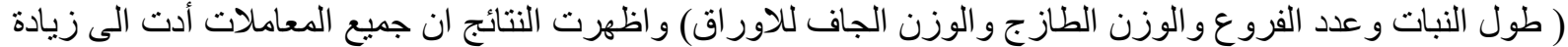

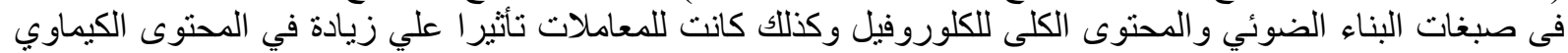

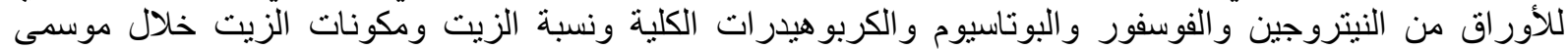
الدراسة وقد أعطت معاملة التفاعل بين مستخلص الطحالب البحرية بتركيز 7 مل/لتر + الثيتوزان 1 مل مل/لتر أعلى نتائج فى جميع الصفات خلال موسمي الدر اسلة. 